\title{
Developments in Multidisciplinary Research and Social Sciences
}




\section{List of Authors}

Živilè Nemickienė - Vilnius University, Kaunokolegija / University of Applied Sciences Kaunas, Lithuania

Poenaru Valentina - Constanta Maritime University, Constanta Romania

Novac Valerian - 'Dunarea de Jos' University, 47 Domneasca Str., Galati, Romania

Bazaitu Razvan - Academia de Politie A. I. Cuza-Bucuresti

Gassim H. Dohal - Gizan, Saudi Arabia

Andrei-Ionut Perdum- Polytechnic University of Bucharest, Romania.

EDITORIAL OFFICE

TECHNIUM PRESS

E.U.

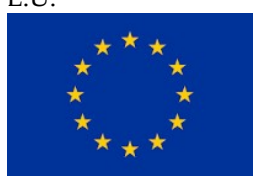

For citation purposes, cite as indicated below:

Developments in Multidisciplinary Research and Social Sciences; ISBN 978-606-95069-3-6, TECHNIUM PRESS: Romania, 2020.

FIRST EDITION 2021

ISBN 978-606-95069-3-6 (PDF)

(C) 2021 by the author. The book is Open Access and distributed under the Creative Commons Attribution license (CC BY-NC$\mathrm{ND}$ ), which allows users to download, copy and build upon published work non-commercially, as long as the author and publisher are properly credited. If the material is transformed or built upon, the resulting work may not be distributed.

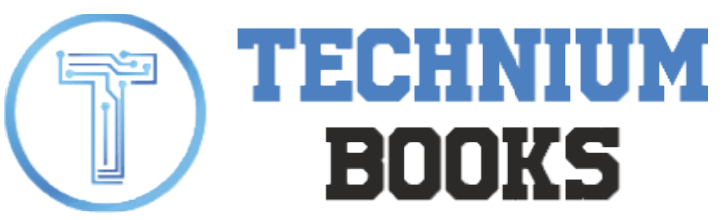




\title{
CHAPTER 1
}

\author{
Živilè Nemickienè
}

\section{PRINCIPLES OF THE EFFECTIVE} LEARNING ENVIRONMENT AND THE FIRST-YEAR STUDENT'S TRANSITION CHALLENGES TO ADULT LEARNING 
Živilè Nemickienė, Associate professor of English and Russian languages at Kaunas Faculty of Vilnius University in Lithuania studied Russian and English languages at Vilnius University defended the doctoral dissertation Systematic Morphonological Analysis of English Long and Short Vowel Oppositions and acquired doctor's degree in 2009. She is a member of the scientific committees for international conferences and a member of editorial boards. Her interests lie in language and translation studies. She has been working as a freelance translator since 2002 and since 1995 as a teacher of English for specific purposes in Kaunas College/University of Applied Sciences.

Preface

The present research analyses one out of multiple challenges the first-year students face during their transition to academic life, and the principles of effective learning environment. The balance, if managed wisely, might become a strong enabler to a successful transition to university life. The study analyses a series of factors, such as the balance of work and rest of the first-year students, skills of time management and the psychological state during the first months at university. The study employs a comparative analysis to evaluate the average hours of work and rest per week of a firstyear student comparing with the planned time. The data of students' work and rest balance was collected from the diary they were asked to record for two months. A focus group was comprised of twenty-five respondents of finance, twelve students of language and three of health science study programs at Lithuanian universities. Criteria of effective principles and teaching / learning environment should be examined by different aspects, such as methodological, sociological, cultural, physiological, educational, psychological, etc. A principle is the central idea, the basic rule of behaviour, expressed in term of necessity or obligation.

ŽivilèNemickienè

ORCID iD: https://orcid.org/0000-0002-4857-0112

Vilnius University, Kaunokolegija/University of applied sciences

Kaunas, Lithuania

\section{Introduction}

The 21st century makes a great emphasis on studies and students. In 2019, the percentage of graduates seeking to enter Lithuanian higher education institutions is higher than last year, which is almost $65 \%$ and is one per cent more than in 2018. The number of students enrolled in 2019 shows that the state funds 7,096 full-time study places in university studies and 4,674 in colleges, and these are places funded just for first-year students [30].

The efforts of the state government are quite considerable, but students' difficulties of adapting to adult learning often undermine the mutual expectations of both students and the state. This problem is not only Lithuanian students' problem as newcomers all over the world face these difficulties. Therefore, many studies, observations, and analyses have been conducted on the subject to determine the ability of first-year students to adapt and integrate into the adult education system [28].

Huge attrition during the first semester is a waste of financial and human resources [14]; moreover, it is a question of reputation of an educational institution [33] and finally, a painful statistical fact in self-assessment report for external experts-evaluators. Kantanis [16] who studied students' changeover to university life and study mode states that even during the first semester period, students make a resolve to continue or quit studies. McInnes [24], James 
[15] analysed students' overall involvement into studies and academic life, development and survival at studies. One of the most prominent factors to go to the wall was pointed out by Goldfinch [11]. The lack of self-management skills results in poor performance at university and dropping out of university. Hillman [14] touched on the question of the first-year students' transition from secondary school to university in Australia. The scholar tried to elucidate the main points that are significant for both newcomers and universities during the process of transition into university academic life. She and other researchers [14], [24], [25], [45], emphasizes the highest percentage of failure among newcomers at universities. Approximately, according to studies [46], [35], nearly 40\% of first-year students quit their studies because of different expectations they had about the university life and the experience during the first year of studies. According to Goldfinch [11], the necessity to earn money for tuition and living is a serious factor to leave studies. Cook [6] adds to this that the attempt to earn for living leads to poor performance at studies, low grades and isolation from university life and its societies. Even when entering university, though successfully, most students feel pressure and tension [13], [46]. The result of all this is stress, which, according to Roberts et al. [36] and Truswell's [42] research, in turn, leads to alcohol and drug problems. As anxiety and depression add up to the case, students often look to coping mechanisms like binge drinking and drugs. Thurber [40] adds homesickness to those hardships and Brown [3] discusses racism. Sinclair [38] emphasises language, academic subjects, and technologies as intimidating factors for newcomers.

The overview of extensive scientific research has presented the current state and dynamic of the issue of a successful transition to university. Research reveals a variety of challenges the first-year students face during their transition to university life mode. The attempt of the present research is to investigate principles of the effective learning environment and understand the first-year students' transition challenges to adult learning and to reveal possible ways of this problem solving.

In order to reveal the reasons of newcomers' failure in adaptation to adult academic life, the following factors are to be considered, namely, the effective learning environment, students' transition challenges to adult learning of the first-year students, their skills of time management and their psychological state during the first months at university. The subject matter of the research is a weekly study load of a first-year student of language and finance study programs in Lithuanian universities.

To reach the aim and objectives set in the present research, the method of the questionnaire was employed, seeking to identify the student's time planning skills. A weekly diary filling method helped to record students' activities during work and rest periods. Methods of scientific and comparative analysis were employed to present relevant theoretical underpinnings. The method of benchmarking and observation were applied [17], [41], [44].

Researchers all over the world keep studying our daily routine, diet and sleep habits of individuals of all ages. The results of long-term research highlighted eventually the differences of habits between women and men elucidating unfavourable impact on health in many cases. Academic youth, due to the specific nature of their activities, forms a special crop having specific factors affecting health adversely, working capacity, and physical condition. These factors are a huge mental workload, usually motionless activities, and lack of fresh air. It is abnormal if students spend up to ten or even twelve hours per day on studies and only three or four hours for rest and leisure. Multiple research literature presents data about insufficient rest and students' sleep duration. Every third student sleeps for less than six hours. Students eating habits are irrational, irregular, and they demonstrate rather low physical activity. The process of developing healthy lifestyles is a complex and long-lasting issue which is strongly influenced firstly by the family attitude to health, and secondly by the school and society as a whole. Purvaneckiene [32] believes that one of the most important 
tasks of a modern higher education institution is to amend students' interaction and build a healthy lifestyle. Young people are the most receptive members of a society; therefore, the focused formation of a healthy lifestyle will help to develop a healthy and perfect personality.

\section{Adults' learning peculiarities}

Methods of teaching adults and children must differ tremendously due to many reasons, and many theories on adult learning prove that. The main points to be emphasized about adult learning are adults' self-regulation, personal motivation, understanding of adults' learning needs and the ways to fulfil them.

\subsection{Adult learners: the roles of self-regulation and motivation}

To find out what role in adults' learning play self-regulation and motivation, the characteristics of adults as learners must be cleared out first. According to Sandra Kerka [19], andragogy enumerates many characteristics of adults as learners. The processes of learning for adults must be meaningful as adult learners are independent, autonomous, and selfdirected. The process of teaching/learning must be designed, taking into consideration learners' prior expertise and experience in the field; therefore, the learning material and resources can be offered rich and diversify significantly. Adults' readiness to learn is related to the ability and need to perform an assignment. They are fully problem-orientated and demonstrate the intrinsic motivation. However, the crucial characteristic of adults is that their participation in the learning process is voluntary. The scholar states [19] "[...] the major difference between adults and younger learners is the wealth of their experience. For others, the capacity for critical thinking or transformative learning is what distinguishes adults." While a child learner, according to her, is a dependent personality, with limited or no experience, whose learning is based on age, learns a particular subject matter, and his/her motivation mainly based on rewards and punishment [19].

Thus, self-regulation, as Zimmerman [49] defines, is the process during which learners set and maintain cognitions and behaviours in motion, which are thoroughly concentrated on achieving aims. Therefore, Boekarts [1] states that to acquire competent self-regulatory strategies, learners must be skilful at forming a cognitive template of their learning goal and be flexible when it has to be redefined. Learners have to be ready to devise a plan delineating their learning objectives, and cognitive strategies intend to use in the performance of various assignments. Monitoring of learner's behaviour is crucially important as that either facilitate or prevent from the aim achievement. Adults perceive learning as a process constantly reevaluating the plan of action taking into consideration its advantages and drawbacks. These metacognitive strategies are indispensable in the learning guiding process at a high school and later university [4]. Unfortunately, many learners have not mastered these tools and do not apply them often, while others are simply unaware or ignore them.

Another reason to develop metacognitive skills is to gain the ability to detect incompetence and do not overestimate personal abilities. Kruger and Dunning [22] state that adults who lack metacognitive skills had faulty self-assessment had difficulties in discerning correct and incorrect answers and were unable to distinguish the superior performances from the inferior ones. Kruger and Dunning [22] state that this disability is a result of the lack of negative feedback received evaluating talents and abilities, negative performance, and attempts to attribute the failure or deficiencies to other factors.

Wlodkowski [48] maintains that the teacher's aim is to elicit learner's inner motivation and encourage to take actions. For example, an employee who are forced by their employer to start certain formal or informal educational programs and who does not believe in the 
benefit of those studies would influence his/her motivation to participate actively in groupwork, discussions, role-plays or presentations. In this case, student's attitude to the learning process would be associated with a variety of cognitive, affective, and psychosocial factors that convince them to be somewhere else better but not in the classroom. Broadwell [2] also notes that some students may not show any willingness to participate in certain classes if they consider the material too non-motivating and straightforward to show up in classes.

DeBord [8] believes that in order to help adult learners develop favourable attitudes towards learning, it is crucial to find out whom the negative attitudes are directed at. He especially emphasized the importance of adult learner's motivational plan, which might help to participate actively in the learning process. Likewise, Wlodkowski and Ginsberg [47] have argued that attention to motivational aspects of learning can become a compelling means to make classroom participation more meaningful. This can be accomplished in various ways, such as developing a personal attitude and meaning strengthening. They speak of the importance of student's need for self-interest and self-determination. According to Wlodkowski and Ginsberg [47], it could be stated that attitude-oriented strategies involve students in objectives setting, providing learning choices, and motivating experiential learning. They also emphasize the need for participation and challenge through the development of higher-order thinking in real-life applications. Meaning can be developed through critical thinking and questioning, decision-making tasks, and creative activities.

\subsection{Meeting adults learning needs}

Unfortunately, the fact that a student is an adult does not automatically guarantee motivation to learn, thus a teacher needs to understand how adults acquire knowledge best. Knowles [20] states that adults have to be free to direct themselves as they are autonomous and self-directed and therefore, must be fully involved in the learning process when instructors perform as facilitators.

Accumulated life experience and knowledge related to adult's work activities, acquired education and other responsibilities, can be integrated into the learning/teaching process. Teachers must help adult students to relate their personal experience and knowledge to the learning contents and to emphasize the benefits of their experience in the learning process.

Usually, adults are goal-oriented and know what goals are to be achieved. Therefore, they appreciate a well-organized study program where instructors demonstrate clear benefits of studies and the ways how the ultimate goals can be achieved.

Adult learners are focused on relevance. They need to see a reason first to start learning something. They would value studies if they saw a clear application and benefits of them in a job or other activities. Hence, the learning outcomes should be precisely defined and elaborated before the studying process starts. The adult learners must be allowed to choose topics of projects closely related to their interests. Teachers must clarify explicitly how the study unit can be or will be useful to them in real life.

Elias and Marriam [9] have noted that adults as learners vary to a very great extent in how they can acquire knowledge and no one theory of adult learning styles could fully satisfy the diversity of needs, experiences, and cultures. However, there can be designed a general structure of learning experiences. Generally speaking, adult learners prefer flexible plans that correspond to their own time restraints.

Usually, adults learn better when their learning is tailored to suit them individually. The current practice of lockdowns all over the world during the pandemic proved once again that adult learners prefer face-to-face learning and avoid distant learning via different learning platforms. This tendency is related to the benefits they gain from alive interactional activities 
with each other, especially when participants are of different age, level of skills, and professional expertise.

Stroot and Keil [39] maintain that the learning environment is of special importance as adult learners learn better in the atmosphere of mutual helpfulness and support of classmates. Adult learners are unwilling to risks; therefore, the study environment must be based on a sense of trust and welcome. They have to feel free to express their views and be ready to accept the viewpoints of others. To implement this, adult learners have clear expectations for the learning environment, and teachers are to meet these expectations.

To sum up the main points on adults' learning self-regulation and motivation briefly can be sated that it is important to take into consideration all the latest progress in meeting specific learning needs, and the learning surroundings or conditions must be physically and psychologically satisfied.

\section{Development principles of the effective learning environment}

To create a positive language learning environment for the first-year students in higher education, as it has been mentioned in the previous chapter, may help a well-organized teaching process.

Effective principles and criteria of teaching/learning environment are manifold and must be evaluated from the methodological, sociological, cultural, physiological, educational, psychological, etc. points of view [50]. Each sphere has its teaching criteria with its specific features; that is why the coordination of these criteria is significant and ensuring the appropriate interaction.

The efficiency of work results is the achievement of a high and socially significant result and product of the final work, fostering meeting the needs of society and consistency of results, aims and objectives. Efficiency is determined after evaluating the costs required to achieve the desired result [18]. The result should be regarded as a national educational standard.

Ghossoon and Sadoon [10] also believe that external efficiency expresses the satisfaction of modern society demands or degree of production correspondence in the labour market, and internal efficiency is the level of achievement of educational institution and performance of specific tasks. Different authors [7], [5], [50] point out the different ways that would be appropriate for efficiency striving, i.e. externally - that is through the sound educational care system, introducing control theory, reducing material costs in education, developing and using new learning technologies, and so on; and internal - implementing the conception of specific objectives, introducing quality evaluation criteria of internal work efficiency at school, which would be a detection rate of social-psychological climate. Among the significant factors of social and psychological climate influencing the overall efficiency, relations between the leading person and its partners, their style, and communication standards can be distinguished.

When a certain educational level of students is reached, the effectiveness of the pedagogical process is described as the use of resources such as time, work, material and technical means or finance, as complex characteristic, which includes institutional indicators of real activity, its potential capacities, the extent of the use of resources and the social climate of educational institutions and finally, the effectiveness can be described as work evaluation of educational institution assessing it according to its final results such as educational degree, the level of social adaptation for life in society, healthcare degree, the degree of implementation of the educational standard [10], [12].

Scientists have investigated two universal criteria of efficiency: effectiveness expressed in units of production corresponding to the expenditure of production (the level of education, 
training opportunities and development, the formation of the social relationship of the students in surrounding reality) [52, 33], [23], [37]; The showed students' satisfaction of individual and group work of educational process is perceived as mental state aroused by certain demands of subjects of labour activity and opportunities their realization.

This opinion is supported by other authors who think that the development of learner's personality is of exceptional importance and the main efficiency indicators [51], [26], [29]. She asserts that if a student received plenty of knowledge but did not feel any joy of that knowledge, or did not perceive himself and others as personalities, it is possible to assert that educational program did not fulfil the set requirements [51, 48-53].

A complex learner's evaluation should be established already in high school. Complex evaluation should include not only a successful grasping of the educational program but such indicators that would evaluate intellectual, social, emotional and physical development. In high school, it is self-realization in professional activity, motivational sphere, investigated by the academic record,

student's dispositions and inclinations and specific individual characteristics such as the ability to work in groups, group leadership, decision making and taking responsibility for that, etc.

While evaluating results, it is necessary to rise the hierarchy of learner's achievements next to the hierarchy of the studying process, which would be comprehensible as student's progress in the educational process, i.e. moving forward from the previous level to the higher level of learning and the result of it is the correspondence to the certain standard of learning [10], [12]. This is completely adaptable in high school as well as in university.

Points mentioned above of efficiency are based on such concepts as "psychological climate ", "teaching subject ", "rational teaching organization ", "social-psychological climate "(social environment), "psychological atmosphere ", "moral environment ", "moral atmosphere ", "moral and psychological climate "and others that are encountered frequently in contemporary science and practice [12].

It should be mentioned that collocations such as psychological climate, or microclimate, or psychological atmosphere are somewhat metaphorical than strictly scientific utterances. The social and psychological climate is one of the people's life activities, and a person acting in one group is not the same as acting in different groups. Moreover, the same person makes a different influence on different group members, and this influence reflects on people's feelings. Thus the main factors of social-psychological climate are vertical and horizontal interrelations, their style and rules of behaviour and different elements of the work environment such as work conditions, a system of lectures and so on. Based on these facts, a stable emotional state of a group can be formed, which directly influences the efficiency of the general activity of members.

Speaking in general, factors increasing the efficiency of the educational environment are learners' interaction and their mutual influence where subjective, social, technological, spatial and material components actively participate matching with teaching/learning aims and objectives and taking into consideration adequate learning principles. Next to this, it is important to apply systematic teaching. Let us take, for example, typical aspectual teaching of a foreign language, the aspects of language are not examined separately. However, they are a part of teaching subject as the aim while learning any of language aspect is a part of a common aim „to learn a language“. Therefore it is important to relate all aspects together, and this relation comes out in the right planned teaching environment which can be displayed in a variety of the context, methods and teaching techniques.

There can be delineated several principles of learning environment, based on the main educational and teaching principles. 
The principle of unity and integrity of the learning environment is one of the most important in the componential structure. The principles of awareness and self-learning motivation emphasize the importance of an individual learner and differential points of view on the learning taking into consideration such components of environment as spatial, technical, social, etc.

The efficiency principle supposes to offer the choice of teaching/learning methods, modes, contexts, and self-study choices for the learner emphasizing at the same time to foster a sense of responsibility, the ability to work in groups, to develop the sense of self-esteem and selfcontrol, the ability to organize individual activities and learning mode. Realizing this principle, the teacher's function is to be a partner to a learner and stimulate student's independence while fulfilling educational tasks.

The interrelation of education and real-life principle is closely related to the principle of visual aids.

Furthermore, creating an educational environment, the control principle is related to the exact organization and technologies. It could be divided into several segments, such as work scheduling, examination, dissemination, implementation, and if necessary, correction of separate segments.

\section{Psychological and pedagogical characteristics of a young person}

As Kralikauskas [21] states, youth is a time of severe crises, great doubts, fluctuations and searching. Literary works of young people from the fourteenth to a twentieth-year-old, such as diaries, letters, or poems, are taken as the main material for the psychological studies. Nowadays, blogging or diary writing is widely recognized as the best source for psychology research of youth. They can be treated as a specific mental document of young adults and adolescents. Psychologists see them as documents that allow researchers to reveal the stage of mental development of the very moment the diary was written.

The young person's life is a time of psychological and pedagogical confusion. It is a period of attitude changes, self-awareness, and understanding of the world. It is time for making a turn from the outside towards inside, towards the inner world. Then the attention is focused on personal inner sensations and experiences. The customs and authorities are critically evaluated, and willingness to check everything, to validate the truth is very strong. The greatest value for a young man is freedom; therefore, the youth is constantly fighting, rebelling, and conflicting with their parents and the people roundabout. They seek to be and prove they are independent and able to take care of themselves.

Along with the elements of adult status, young adults still retain some features of dependence. Their position somewhat reminds that of a child. The senior school students still fully depend on their parents. At school, on the one hand, they are told that they are adults, and on the other, they are required to show obedience constantly. In Lithuania sometimes this is true even for 20-year-olds who are not considered adults in certain circumstances, e.g. according to Lithuanian laws, young people over the age of eighteen can get married, defend their homeland with a gun, but cannot buy alcohol before the age of twenty-one. According to Petrovskis [31], the uncertainty of this situation (in some cases they are accepted as adults, in other cases they are not) and the requirements placed upon them, reflect in their psychological state.

Thus, choosing a profession is the first step to independent social life, and the chosen profession indicates a position in society. It is the very moment when young people begin to appreciate the completeness of life. And then the statement "I live here and now" disappears. They are determined to pursue set goals, to create projects and future prospects. 


\section{The phenomenon of procrastination}

Procrastination is one of the serious causes of first-year students' failure in the transition process to adult learning. Procrastination can be shortly defined as the action of delaying or postponing something. However the very phenomenon from the cognitive behavioural perspective is much more complex.

Procrastination can be described as a state when a person is ready to take actions but cannot start due to a high level of anxiety, as if his/her thoughts are in stagnancy. Just like, for example, writers who sit looking at a clear white screen of the computer and cannot write a sentence, students feel the same way.

Procrastinators avoid doing significant work, or assignment but instead evolve themselves in other not very significant though more enjoyable activities. They develop a harmful habit of constant postponing important but unpleasant work.

This habit decreases the procrastinator's self-esteem. The procrastinator realizes that he/she is wasting time realizing there is less and less of it to perform a task and experiences tremendous stress because negative emotions dominate. Wasted time leads to or presupposes poor results and the learner understands or experiences this, able to soberly assess the lost opportunities, thus underestimating himself and losing confidence.

Research shows [34] that every fifth person can be characterized as a procrastinator. More than 80 per cent of students have a delay related difficulties and $90-95$ per cent of the general population at least once have postponed their jobs, studies, etc.

Rasch\&Rasch [34] presented and described the cycle of procrastination and listed the main reasons and steps in this cycle.

Unclear and unrealistic goals and denial of the problem is the first obstacle to start the assignment. Fear of failure causes anxiety, regret and boredom. Another obstacle that foster procrastination is self-encouraging and daydreaming about pleasant though unrealistic plans. Avoidance is predetermined by fear of work, anxiety about the results and self-criticism. Anxiety naturally increases when the deadline approaches, which causes permanent and heavy involvement in the working process. Moreover, disappointment descends when work is done but needs lots of rationalizations transformations and remakes.

The situation can be easily managed if the student is aware of the problem. The learner must first understand what type of procrastinator s/he is. Moran [27] states, the worrier does not start the important assignment because s/he does not believe in the successful completion of the task.

The worrier uses the phrase "what if" and sees risks everywhere; therefore, it becomes challenging to make a decision and get started. Thus they prefer to stay in a comfort zone and do things they already know.

The perfectionist is afraid of failure as believes that the task is completed if only done perfectly. S/he wants to do everything perfectly well and pays close attention to details. This gives a clear understanding that time reserve is too limited for all details to complete and submit the assignment on time and therefore, thinks there is no point to start if it is impossible to do perfectly. As the perfectionist understands, it is impossible, feels negative emotions and tension.

The over-doer is incapable of prioritising assignments and failing to submit them on time. Such people take all assignments without any refuse as they cannot say 'no' and think are ready to help everyone. They cannot differentiate assignments, as all work seems equally important. The over-doers are constantly drifting between assignments and activities doing one or another and not finishing any of them.

The crisis maker needs to be under stress and pressure. Such students believe that under pressure, they can allocate their inner recourses and complete the task the last minute. Such 
adrenaline maniac thinks that work results are the most effective when there is high tension and stress as such people like to feel the adrenaline rush.

The dreamer strongly believes that life cannot be only hard work. Such people have great ideas and plans; however, do nothing to implement them but wait for them to come true by gravity. Such people talk about assignment and plan a lot, but they only talk. Plans and tasks stay in dreams and are never implemented.

The last type of procrastinators is defier. Such people better like to choose the assignment and initiate their implementation rather than be appointed by somebody. Therefore it is difficult for such people to start an assignment if they consider it is unimportant or meaningless and refuse to obey as do not like when others tell what to do and how to do it.

\section{Basics of student activities, rest physiology and hygiene}

Planning the balance of work and rest means a rational combination of various activities and rest at a certain point in time. Vaitkevičius [43] describes it as a combination of reflexes of certain conditioned and unconditional actions and time, which at the same time form very close neuropsychological connections. In fact, it is a dynamic stereotype, a chain of conditioned and/or unconditioned reflexes embedded in the cerebral cortex.

Activities and rest time of a young adult consist of such elements as nutrition, housekeeping, studying, social activities, etc. Thus, if time management is rational and well planned, it positively affects the health, physical and mental activity of the young adult and his/her psycho-emotional state.

A well-planned balance of activities and rest helps children, adolescents and young adults to overcome not only the problems of physical, but also mental development. The skills of self-knowledge, communication, cooperation, decision-making and implementation will strengthen the dynamic stereotype of activity and recreation. Rational time management will solve all the problems of mental and physical development of children, adolescents and youth.

Young people should be aware that the balance between work and rest, as well as rational planning of this balance, are of paramount importance to them and personal experience might help to understand this. Having acquired the basics of activity and physiology of rest, they could behave more flexibly and independently in different situations, such as giving up "fashion" or peer pressure on addictive habits, laziness, etc.

\section{Research design}

A focus group was comprised of twenty-five students of finance, twelve students of language and three of heath science study programs at Lithuanian universities. The organization of the research of work and rest management peculiarities for the first-year students was started by instructing students on the course of the research and their responsibilities, etc. forty respondents were familiarized with data collection methods, i.e. weekly filling blog for two months (mid-Oct. - mid-Dec.) and the questionnaire. The theoretical underpinning of the research is based on scientific literature using a comparative scientific method of analysis. Students of different universities have demonstrated the same tendencies in time management; it had no sense to discern the results of different institutions when analysing data.

After analysing the respondents' questionnaire, it was assumed that everyone lacks time planning skills. The answers in the questionnaires revealed that nearly all respondents were on the verge of chaos. An analysis of weekly diaries also showed that first-year students lacked the skills to plan work and rest hours. Thus, in these two analyses, students were found to have gaps in their time planning. Analysis of the diary clearly showed that the emotional state is not positive. Consequently, respondents are not satisfied with their time 
and rest management; however, the lack of skills and motivation prevents them from planning more accurately. Based on the recorded data, the analysis was performed.

\section{Analysis of a first-year student study-load}

Research tools of the research are methods of scientific and comparative analysis. A comparative analysis was employed to compare the hours of work and rest per week of a first-year student with the planned time, which makes eight hours for work, eight hours for sleep, and eight hours for rest. This balance of hours is based on the first-year student's weekly diary. Weekly monitoring, work and rest recording helped to reveal and evaluate the peculiarities of student time management.

In the qualitative stage of the research uses data obtained from the questionnaire, which provided ten statements and the diary which first-year students were asked to complete for two months. The questionnaire offered the following open-ended questions:

\section{I think that day-to-day planning is a waste of time.}

The respondent states his/her opinion on time planning without knowing the results. The answer informs about the respondent's general approach to time management and a positive answer to this question indicates that the respondent is not interested in time planning. Students describe their life as a constant routine that is not necessary to plan. However, especially daydreamers must make a 'to do' list, set reminders and start implementation from the essential assignment setting personal deadlines.

2. My learning goals are clear enough.

This question shows whether respondents have clear goals and know what they are striving for. Without knowing the goal, it is impossible to plan for the time. The answer to this question demonstrates the researcher's attitude and knowledge in the professional field. A negative answer indicates that students do not have sufficient knowledge about the learning objectives, which negatively affects their time planning. It is also related to an unwillingness to seek guidance or help from qualified academic staff. Most of the time, the newcomers followed the precursors' practice and advice via Facebook or face to face communication.

The assignment that seems boring or insignificant should be analysed closer, finding out why this assignment might be important or necessary, what benefits it may offer. When taking on any specific task, the first thing to do is to find out its terms and conditions in order to avoid ambiguous situations.

3. Procrastinating tasks until the last minute is a big problem for me.

The answer to this question demonstrates the respondent's understanding of the procrastination problem. Respondents do not admit they have problems with completing tasks on time; thus, they do not plan when they are going to complete them, though procrastination according to the diary has financial, psychological and social reasons.

The procrastinator understands $\mathrm{s} /$ he is wasting time and suffers from high stress and negative emotions. The result is low, and lost opportunities reduce learner's self-esteem and self-confidence. Thus, it is important to understand that the main reasons for procrastination are lack of motivation, poor time planning skills and fear of failure.

However, filled with panic, a first-year student is mentally constrained for a while. This state can be treated as a step backwards assessing the situation. A decision of doing nothing until can understand what and how to do is also a decision. Considering what the outcome would be in one case or another may suggest options for what could be done to overcome the obstacles that prevent the start of an activity. The focus should not be on risk, but on how much and what kind of success can be achieved.

\section{I organize my time very well.}


It is important to ask this question to find out the student's approach to time management. A positive answer indicates that students correctly assess their knowledge of time management and understand the inadequacy of that knowledge.

It is significant to improve time planning skills. The first skill to be developed is to learn how to set priorities of activities, to apply the economic principle called Pareto Law, known as the law of the vital few, or the principle of factor sparsity the 80/20 rule. When scheduling work it is better to start with the most important and/or complex tasks. Once the plan of actions is ready, it is crucial to avoid any disturbances but schedule some time for accidental and unplanned activities. Having achieved the goal, it is wise to think about a reward for successful work.

\section{I would like to be more motivated to plan my time.}

Perception of the general quality of studying allows students to plan their time in a motivated way; however, if respondents do not understand the meaning of knowledge, they answer this question negatively.

The most challenging task is to find motivation when it is clearly lacking. A first-year student should actively seek for help. Having a determination to solve the problem independently, it is necessary to segment a large and at first glance insurmountable problem into smaller stages. Naturally, many tasks and formulations may be unclear for a first-year student. It may look like everyone understood the task except me, but no matter how it is there if the task is unclear, the only right decision to find a way out of the impasse is to clear out the meaning and significance of the assignment, to specify it and its conditions. The longterm practice has repeatedly proven that boring or too easy assignments do not motivate. The unwillingness to perform an assignment sometimes lead to contemplations about quitting studies. The right decision is to ask for a more complex assignment matching personal competencies and knowledge.

6. It is easy for me to finish or postpone a conversation with people who come over while I am studying.

This question helps to find out how respondents are able to allocate their time to complete necessary and unimportant tasks and if they are able to say NO to various distractions. If respondents give a negative answer, they not ready to complete intended plans and take a chance to defer them. It should be emphasized that the "distracting factor" should be understood not only as a lively presence of visitors but also as a presence on social networks and smartphones, which can distract students more often and disrupt their focus. Students should turn off the sound or, even better, remove their phones and other gadgets from their eyes. It is important to pay more attention to modern technology than it did before. The inability to stop distractors is one of the reasons for procrastination, which respondents basically do not admit. On the other hand, this socialization during the first months of academic life is sometimes vital.

\section{People feel free to visit me at any time.}

The answer gives a hint about the attitude of others towards the respondent's time, i.e. time devoted to communication. The question answered affirmatively proves that guests take liberties with the respondents' time because the respondents are not able to show that they have important or urgent work, and communication should be postponed.

8. I know when it is important to focus and when to relax.

This question examines whether respondents have skills in the distribution of work and rest. The negative answer indicates unawareness when it is the best time to work or rest. The diary disclosed that respondents do not plan or sometimes think they are not able to plan their work and rest time. They state that if it is impossible to change the schedule of certain event, then the process of planning is impossible and meaningless. 
The important thing is to learn to say "NO" not only for distractors but for extra work too and when saying "YES" to understand what and how much you will have a sacrifice. Thus it is essential to set clear priorities for activities-for example, Pareto's law.

Working time, as well as leisure time, is limited. Therefore, it is possible to plan only as much work as is allocated to working time a day without sacrificing rest time because life is not only work but also leisure, recreation and hobbies.

9. Whatever I do, I try to do it perfectly.

The answer shows how seriously the respondents are determined and strive for excellence. If the answer is no, respondents do not even try to perform work perfectly; it is possible to connect this answer with the answer to question No. 2 - the respondent does not have clear learning objectives. However, high standards should be the ultimate aspiration, but not the absolute. For a smoother integration, perfectionists must reduce the personal standards of daily tasks completing the assignment in small steps, setting time limits and trying to fit into the set frames. Understanding the bigger picture of the work scope distracts from unnecessary details letting enjoy the process.

10. I have enough free time.

If the answer is positive, respondents most likely are able to plan their free time more properly and achieve better results in having a balanced working and resting time. Unfortunately, respondents do not have enough time, as time is "eaten" by unwanted timewasters.

The way time is planed shows what kind of person is and who wants to be. Vaitkevičius [43] states, those who care about their future, worry about time management, i.e. a way to control and plan our time.

\section{Analysis of research data and discussion}

According to the weekly diary of respondents, data on sleep, nutrition, science, personal hygiene, and leisure hours per day were grouped and represent the average distribution of hours per week (168). Five hours per week, respondents devote to eating and personal hygiene. These two activities took the least amount of research time. Given that personal hygiene and nutrition are perhaps the main indicators of well-being, students should pay special attention to this more responsibly.

The studying comprised 34 hours of all-week time. Although this is not a very serious deviation from the recommended 40 hours per week, the remaining 6 hours should still be used for studying. All learning hours are extremely vital, and especially first-year students should spend most of their time reading and researching.

More hours are devoted to sleep. On average, students spend 51 hours a week for sleeping. This is far more hours than for studying, but none of them reached the recommended 56 hours of optimal sleep. In addition, diary analysis revealed complete chaos in students' sleep mode. Students do not follow any sleep patterns, for instance stay up late till 3 am or longer, then sleep when they feel very tired or during a short break after lectures. The first step they should take when planning time is to balance their sleep patterns. Poorly rested students are neither efficient nor psycho-emotionally strong. This naturally leads to a decline in motivation for studies and its further consequences.

Most of the time (78 hours) is spent at leisure. This number of hours includes a trip to the lectures and back, a trip home and back to the city of study in Kaunas. 


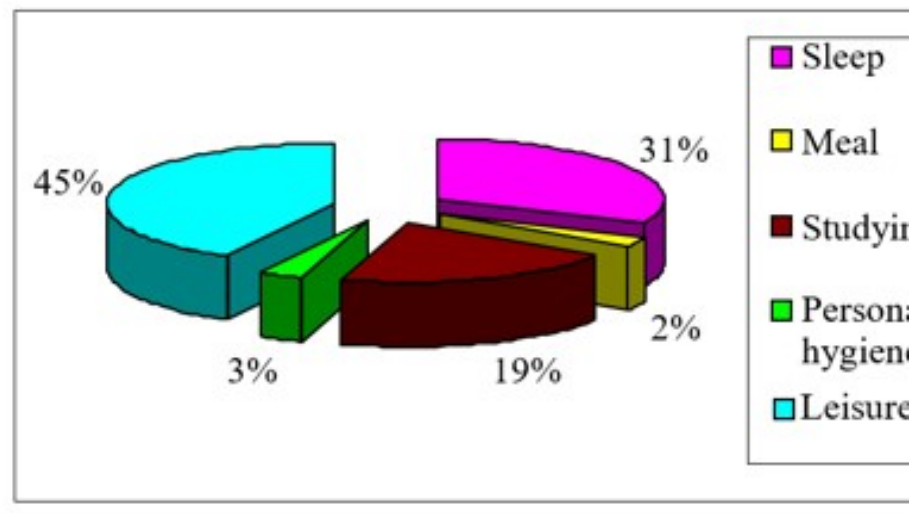

Thus, the statistics for the distribution of time are as follows: the total number of hours per week makes $100 \%$, i.e. $2 \%$ is devoted to meals, $3 \%$ is devoted to personal hygiene, $29 \%$ of the total hours are devoted to studying, sleep occupies $31 \%$ of the time and $45 \%$ is devoted to leisure.

The average work and rest daily hourly balance based on the diary will be discussed below. Here, leisure activities include such activities as personal hygiene, eating and travelling to lectures.

Monday. There is an equal amount of time allocated for studies and sleep, namely, for six hours to each. Thus, free time leads. Even twelve hours were allocated for it.

Tuesday. Time distribution on Tuesday is not even. Students spent too much time studying and sleeping at the expense of leisure hours. Ten hours were allocated for studies and sleep, and only four hours for leisure.

Wednesday. Five hours were devoted to sleep, twelve hours to study, and seven hours to rest. Thus, on Wednesday, students spent too much time studying and exceeded the recommended working time by an average of four hours. This distribution of time leads to fatigue and disability.

Thursday. The balance between studying and sleep time is quite different on Thursdays. It is obvious that this distribution was due to the peculiarities of the lecture schedule. On this weekday, twelve hours were devoted to sleep and four hours to studying. Meanwhile, leisure time comprises eight hours. Since the students slept little on Wednesday and spent a lot of time studying, they report that their fatigue affected study results and the overall day was counterproductive.

Friday. Nine hours for sleep, three hours for studying, twelve hours for rest. It should be noted that there is not enough time to studying the second day in a row. Free time exceeds the recommended number of hours by 4 hours.

Saturday. Saturday is considered a working day in Lithuania and the study time was significantly longer than during the previous two days, i.e. on an average as much as seven hours. Meanwhile, sleep and leisure time are unbalanced. There are five hours allocated for sleeping and twelve hours for leisure. Students had free time at the expense of sleep.

Sunday. Sunday data reflect what was expected; namely, most hours were devoted to sleep - on an average nearly thirteen hours. Free time comprises eleven hours. There was no time to study at all. It can be argued that the data is not critical because Sunday is not a working day. 
Having studied and analysed the data and stricken an average, it can be concluded that the time management of the respondents is quite poor. First-year students spend too much time on leisure and too little time on sleep. The total weekly average of sleep, studying, and rest is far from the norm and is very irregular and even chaotic when looking at the daily distribution of time.

The analysis of the diary revealed that students rely more on precursors rather than on the guidance of qualified academic staff, which prevents from optimal planning and goal setting. Some indirectly related challenges to time management were revealed, namely, homesickness and lack of feeling being associated with, or being a part of the institution they belong to now. Respondents indicated that twelve years at secondary school made it their home, and it is what they miss at university. This partially explains why students feel homesick, and instead of being at lectures, they prefer staying at home and search for information about academic life and lectures via Facebook distantly. 95\% of those respondents who live in periphery leave campus on Thursday evening despite the fact that they have lectures on Friday. This state of facts determines a high percentage of leisure time in respondents' diaries. Respondents also indicate that after two months of studies, they feel tired and depressed and have to force themselves (sometimes unsuccessfully) to leave home for university.

The lack of sleep is also closely related to the problem of study costs, vitally necessary employment, and mid-semester tests and seminars period. All these problems eventually lead to insufficient rest and dissatisfaction of academic life. All finance students and nearly half of language students started working in the city of university prior studies in summer and continued working when lectures started, regardless of whether they received a state-funded or paid position. Desire to earn and be independent prevents from participation in lectures, and consequently, extra money gives occasion for spending it.

Thus, having such work and life pattern, in two months when mid-semester tests session begins, students are tired, sleepless and depressed.

Procrastination is often caused by poor learning skills, such as learning by heart, lack of critical thinking skills, which are brought from high school. For example, in foreign language classes at university, such students try to memorize and retell the material and when asked for their personal opinion, sometimes cannot form even a sentence. This sets them apart from other, fluent-speaking students and strongly demotivates them.

As the study showed, a vague, too /complicated, unpleasant or merely uninteresting for some reasons assignment leads to procrastination. The young generation of the 21 st century are increasingly stating that they do not choose studies based on future employment or earnings prospects, but on intangible things that bring them happiness and enjoyment. If assignments are unclear, uninteresting or require too much effort to complete, the study program may lose attractiveness. Students expect assignments that are meaningful for them. If it turns out that the aim and objectives of the assignment are unclear - the work will be procrastinated. The study revealed that there are first-year students who demonstrate the opposite extreme, namely, the tendency to commit too much, which also leads to failure when all commitments fail to be met. Fear of change is another barrier to a successful transition to adult learning. The fear to change something that has worked perfectly well for more than ten years is another reason for procrastination leading to unsuccessful integration into adult studies.

Excuses are an integral part of procrastination. The tactics of looking for excuses should be necessarily changed. The excuses must be altered to the analysis of the situation, starting with asking a simple question about if there is anything significant I can do today. To get the work moving from the point of death, it is wise to divide a big, unpleasant or intimidating project into small everyday assignments. A created environment that is not distracting but 
encouraging to work leads to positive thinking. Naturally, positive thinking presupposes positive consequences; however, to achieve positiveness instead of excessive self-criticism, the self-analysis is critical here. On the other hand, students need to evaluate their performance soberly, to admit procrastination and to thing how the situation can be changed.

Though first-year students indicated some difficulties adapting to different teaching styles, expectations and workloads, in general, they indicated that the infrastructure, such as labs, library, study areas or access to Internet and other facilities provided by universities did not cause time planning problems and were mentioned as very helpful and even excessive comparing to secondary school potential.

Thus, it is not surprising that respondents living in this rhythm for four months feel tired, depressed and often incapacitated. The study clearly showed that not too much workload determines this condition and a lack of basic knowledge on how to manage time.

\section{Conclusions}

The survey established students' work and rest current mode and revealed that the respondents have no time work and rest management skills. Students should pay more attention to planning and setting priorities.

First-year students spend too little time on learning (34 hours) and too much time (42\%) on leisure activities. Sleep hours are too short -53 hours comparing to recommended 56 hours. A poor psychological state mentioned in the diary is indicated only when students are not prepared for classes or have not completed assignments, spent little time studying and had not rested. This psychological-emotional state of the respondents is closely related to time management skills. A lot of free time is wasted due to unnecessary time wasters (guests, phones, social media), as respondents are unable to say that they are busy and cannot postpone the communication to a later time. Thus, first-year students must learn or be taught to set goals grouping the day's assignments according to its importance and urgency, i.e. prioritize day activities and assignments. Universities should organise interviews and discussions on time management for first-year students, to expand on the university course of Introduction into Studies on the basis of this research results, to offer additional to existing orientation and first-year student support programs that would help to dissociate from secondary school and integrate to university life. This should be done by professional academic staff rather than or along with social networks. To have successful results, students, in turn, must demonstrate a personal interest in time planning, prove their willingness and motivation. The purpose of the teacher is not to motivate students, but rather to elicit and encourage the motivation that is already present within them. Compared to children and teens, adults have special needs and requirements as learners. It is essential to place recent developments in meeting specific adults learning needs so that the learning was physically and psychologically comfortable.

\section{References}

[1] Boekarts, 1996. Self-regulated learning at the junction of cognition and motivation. European Psychologist, 1, pp. 100-112.

[2] Broadwell, G. A. 1996. Directional particles and abstract motion in Choctaw. Proceedings of the 1996 Mid-America Linguistics Conference (pp. 53-66).

[3] Brown L. 2013. Encounters With Racism and The International Student Experience, Studies in Higher Education, Vol. 38, No. 7, $1004-100$ 
[4] Brown, K. M. 1999. Social cognitive theory. University of South Florida.

[5] Conner, L., Sliwka A.2014. Implications of Research on Effective Learning Environments for Initial Teacher Education. European Journal of Education 49(2) DOI: 10.1111/ejed.12081 [6] Cooke R., Barkham M., Audin K., Bradley M. 2004. Student Debt And Its Relation To Student Mental Health. Journal of Further and Higher Education; Vol.28 (2004) 54-66. DOI:(10.1080/0309877032000161814).

[7] Day, K. 2009. Creating and Sustaining Effective Learning Environments. AISHE-J. Volume 1, Number 1

[8] DeBord K., 1996. Refreshing your memory on adult learners. (Available at Internet: http://www.ces.ncsu.edu/depts/fcs/nnfr/adult lrn.htm). Consulted on 2006-09-15.

[9] Elias J. L., \&Marriam S., 1995. Philosophical foundations of adult education. Malabar, FL: Krieger Publishing Company.

[10] Ghossoon, M.W.,Sadoon, A. 2017. New Strategies to Develop Effective Learning Environments that Support Learners: Real Practical Cases in World Journal of Research and Review (WJRR), Vol. 5, Issue-2, pp. 25-28

[11] Goldfinch, J., Hughes, M. 2007. Skills, Learning Styles and Success of First Year Undergraduates, Active learning in higher education, vol.8 (3) 259-274 DOI: (10.1177/1469787407081881)Moore.

[12] Graham, Ch., Lim, B., CranerJ., DuffyTh. 2000.Seven Principles of Effective Teaching: A Practical Lens for Evaluating Online Courses. The Technology SourceArchives. [13] Greenbank P. 2007. From foundation to honours degree: The student experience. Education and Training, 49(2), 91-10, 2.

[14] Hillman, K. 2005. The first year experience: The transition from secondary school to university and TAFE in Australia. In Longitudinal Studies in Australian Youth, Research Report No 40. Camberwell, Vic: Australian Council for Educational Research.

[15] James, R., Krause K., Jennings C. 2010. The first year experience in Australian universities: Findings from 1994 to 2009. Centre for the Study of Higher Education, University of Melbourne.

[16] Kantanis, T. 2000. The role of social transition in students' adjustment to the first-year of university. Journal of Institutional Research, 9(1), 100-110.

[17] Kardelis, K., 2002. Moksliniutyrimumetodologijairmetodai : (edukologijairkitisocialiniaimokslai). Kaunas: Judex. P. 398.

[18] Kasiulis, J., BarvydienėV., Vadovavimo psichologija. Kaunas. Technologija. 2004

[19] Kerka, S., 2002. Teaching Adults: Is It Different? Myths and Realities No. 21. (Available at Internet: http://www.cete.org/acve/docs/mr00036.pdf). Consulted on 2006-0915 .

[20] Knowles M. S., 1970. The Modern Practice of Adult Education. Andragogy versus pedagogy. Englewood Cliffs: Prentice Hall/Cambridge.

[21] Kralikauskas, J. 1998. Psichologijosțtvadas, 296-299.

[22] Kruger, J. \& Dunning D., 1999. Unskilled and unaware of it: how difficulties in recognising one's own incompetence lead to inflated self-assessments. Journal of personality and social psychology, 77 (6), 1121-1134.

[23] Li X., 1984. In defence of the communicative approach. ELT Journal 38/I: pp.2-6. Oxford: Oxford University press.

[24] Mcinnis, C., 2001. Researching the first year experience: Where to from here. Higher Education Research And Development, 20, 105-114.

[25] Mcinnis, C. 2002. Signs of disengagement: responding to the changing work patterns of full-time undergraduates in Australian universities: Higher Education in the 21st Century, London: Elsevier.

[26] Medgyes P., 1986. Queries from a communicative teacher. ELT Journal 40/2, pp. 8-10. 
[27] Moran, J.2020. 6 Types of Procrastinators and how They Think. Performance, Development \& Wellbeing Psychology. https://www.jaysonmoran.com/

[28] Nemickienè, Ž.,Nemickaité E. 2019. First-year student's work and rest balance as an enabler to transition to adult learning.A new decade for social changes. Technium social sciences Journal. Vol 1.

[29] Pattison, P., 1987. Developing communicative skills. Cambridge: Cambridge University Press.

[30] Patvirtinti ị valstybinesaukštąsiasmokyklaspriimamųstudentųskaičiai. Accessed on 2020 Jaunuary 12]. Accessed at: < https://bakalauras.lamabpo.lt/2019-m-priimtuju-i-aukstasiasmokyklas-skaiciai/ $>$.

[31] Petrovskis, A. Nepomniašciaja, N. Muchina, V. et al. 1987. Amžiaustarpsniųirpedagoginèpsichologija :mokymopriemonèpedagoginioinstitutostudentams.

[32] Purvaneckiene, G. 2000. Lyčiųskirtumaišvietimosistemoje. Vilnius, 92-93.

[33] Ramsay, S., Elphinstone, L., Vivekananda, K. 2003. Utilising an organisational learning approach to facilitate change in a university and improve the retention of first year students. Proceedings of 11th International Conference on Post-compulsory Education and Training, at Gold Coast, Australia.

[34] Rasch, D., Rasch, M. 2013. Understanding the Procrastination Cycle. The Learning Curve. USC Law Legal Studies Paper No. 13-14.

[35] Rickinson, B., Rutherford. D. 1995. Increasing undergraduate student retention rates. British Journal of Guidance and Counseling, 2, 161-172.

[36] Roberts, R., Golding J., Towell T., Reid S., Woodford S. 2000. Mental and physical health in students: The role of economic circumstances. British Journal of Health Psychology, 289-297.

[37] Schelleken, P., 2004. EFD and ES(O)L common learning needs, common teaching goals. LATEFL Brighton conference selections Ed Alan Pulverness.

[38] Sinclair, C. 2006. Understanding University. Maidenhead Open University press.

[39] Stroot, S., \&Keil V., 1998. Peer assistance and review guidebook. Columbus, OH: Ohio Department of Education. (Available at Internet: http://global.cscc.edu/tlrc/Articles/Adult $\% 20$ Learning\%20Style1 1.pdf\#search=\%221.\%20A dults $\% 20$ prefer $\% 20$ flexible $\% 20$ schedules $\% 20$ that $\% 20$ respond $\% 20$ to $\% 20$ their $\% 20$ own $\% 20$ ti me\%20constraints $\% 22$ ).

[40] Thurber, E. A. 2012. Experiences From The Field, Homesickness And Adjustment In University Students. Journal of American College Health, Vol. 60 No.5, 415-418.

[41] Tidikis, R., 2003. Socialiniųmokslųtyrimųmetodologija. LTU leidykla. P. 626.

[42] Truswell, N. 2019. Student depression on the increase. The Independent, 08 July 2008 Available at:http://www.independent.co.uk/student/news/student-depression-on-the-increase862336.html, Accessed on 30 July 2019.

[43] Vaitkevicius, J.V. 2003. Laikovadyba. ŠiaurèsLietuva, 6-9.

[44] Valackienè, A., 2004. Sociologinistyrimas. KTU Technologija. P. 147.

[45] Williams, C. 1982. The early experiences of students on Australian campuses. Sydney: University of Sydney.

[46] Wintre M., Yaffe M. 2000. First-year students' adjustment to university life as a function of relationships with parents. Journal of Adolescent Research, 15(1), 9-37.

[47] Wlodkowski, R. J., Ginsberg, 1995. Diversity and motivation: culturally responsive teaching. San Francisco, Jossey-Bass Publishers. W56.

[48] Wlodkowski, R. J. 1998. Enhancing Adult Motivation to Learn: A comprehensive guide for teaching all adults. Jossey-Bass. 
[49] Zimmerman, B. J., 1989. A social cognitive view of self-regulated academic learning. JournalofEducationPsychology, 81, pp. 329-339.

[50] Божович, Е.Д. Психолого-педагогические критерии эффективности обучения и принципы построения контрольно-диатностических заданий. Науч. Трудов / Под ред. Е.Д.Божович. - м.: МП Новая школа, 2008. с. 5.

[51] Новикова, Т.И. Цель обучения - учащийся, его идеи и мьісли // Директор школ. 1994. -No.22 c. $48-53$.

[52] Петровский, А.В. Быть личностью. - М.: Педагогика, 1990.

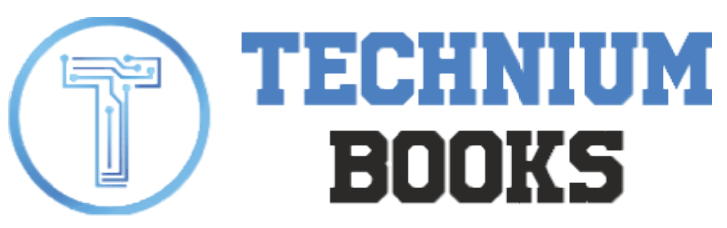




\section{CHAPTER 2}

Poenaru Valentina, Novac Valerian, Bazaitu Razvan

Classical and modern methods in maritime education for analysis and interpretation of Meteorology and Oceanography factors influencing shipping and marine environment in west of the Black Sea.

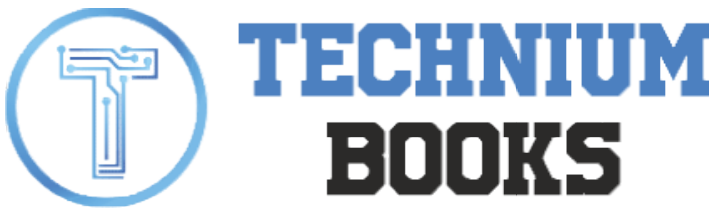




\section{Introduction}

Socio-economic and political conditions at the beginning of the XXI century (the negative influence of the global crisis extended in recent years) have imposed significant challenges on international shipping, amounting to almost 10 billion tons of freight transported, almost four-fifths of global trade. Shipping, thus invariably becomes a significant branch of the global economy bearing primary role both in quantity and quality among all other communication means. Further, the evolution in transport technologies in modern times has adversely affected shipping due to reduced cost of transport on the one hand, and diversification of international trade relations on the other.

Due to these reasons, the global maritime fleet (over 90,000 merchant ships in 2019) has seen unprecedented development, reflected in the increase in total tonnage (1.9 billion dwt in 2019). Along with this evolution, evolved diversification of types of ships and specialization in shipping increased, the tonnage unit and the speed of the march, automation in the functioning and operation of the board and the ship, improved working conditions on board, increased the safety and security of crews, and widening of waterways areas.

Although progress has been rampant in other modes of transport, freight vessels remain the primary means of transport in international trade. The ascendant of these vessels is particularly evident when considering percentage of goods transported through sea and its overall value in global trade.

As an economic activity, maritime transport cannot be limited to improve economic profitability, but requires an objective necessity of development of human society in its geographical, economic, and political stability, No other means of transport can provide costeffective and massive cargo volume trade that is subject to international economic exchanges.

The Black Sea looks to resemble a deep pool oriented from west to east, which spans the length of six degrees latitude and breadth five degrees longitude, between parallels and meridians $40^{\circ} 055^{\prime} \mathrm{N}$ and $46^{\circ} 037^{\prime} \mathrm{N} 27^{\circ} 027^{\prime} \mathrm{E}$ and $41^{\circ} 047^{\prime} \mathrm{E}$. It is an excellent interconnection linking the Bosphorus, the Mediterranean Sea and Kerch Strait, the Sea of Azov.

2. Principal phenomena that manifest in the oceans (waves, tides, sea currents, freezing and thawing, and sound propagation) and significant oceanographic parameters variation (salinity, density, temperature) affect directly and indirectly navigation, condition of the ship and cargo and crew wellbeing during the voyage at sea.

Meteorological and oceanographic navigation is the branch of modern maritime navigation using statistical and oceanographic data in real-time to optimize the route and reduce the risks for the ship, crew, and cargo. Education and training should be able to provide potential officers with the highest quality training and the ability to provide multiple employment opportunities. Professional training for shipping and related sectors, but also marine engineering and fishery, should be under review continuously.

The aim must be to ensure that all institutes of higher maritime education graduates to provide training to international standards such as those prescribed in the Standards of Training, Certification, and Supervision "Standards for Training, Certification, and Watchkeeping" (STCW Convention). They pose a range of additional skills, which correspond to the needs of the maritime industry and enable them to enhance their employability and increase their competitiveness. The superiority of the institutes depends on attracting the best young men and women in education and training in the maritime field. In this way the high training quality image of this sector increase. It is essential to ensure proper working conditions and living conditions for seafarers, both men, and women. The objective of any owner should be to have quality ships, led by skilled and well-trained seafarers who work in the best conditions.

Currently planning a voyage at sea cannot be conceived without forecast and oceanographic information available, accurate, and up to date about the sea areas crossed. 
Numerous studies of sea crossing and ocean show benefits of proper voyage planning with the assistance of oceanographic forecasts, thus it is accurate to say that updated information assists in saving time and fuel, increases the safety of the crew, passengers, and cargo carried.

During the sea voyage weather and oceanographic information fully and promptly provides a basis for modifying the ship's passage to optimize routing in unfavorable weather conditions, which requires good knowledge of the navigator of marine meteorology and oceanography notions.

Equipping ships with modern instruments and apparatus for meteorological and oceanographic observation is essential, systems such as satellite surveillance exist and oceanographic and meteorological information. Appropriate knowledge of marine meteorology and oceanography is now a standard requirement of modern navigation.

In the practice of navigation, it is essential to have a statistical analysis of the sea agitation, expressed numerically wave elements (height, period length, the overall direction of travel), and weather-oceanographic factors that generate them.

During navigation on dangerous waves, the greatest danger is the phenomenon of resonance. Resonance means a coincidence period when the oscillation of the ship coincides with the apparent wind wave period. Apparent wind wave period depends on the speed of the march and the angle between the path of the ship and wave direction.

The behavior of the ship at sea under the action of the wave oscillations are characterized by complex forces, followed by undesirable phenomena caused by the occurrence of accelerations andlarge inertial forces. Among the critical issues is the need for improved damage stability of cargo ship and aggravated psychophysical effects on the crew because of seasickness. Due to the complexity of the phenomena accompanying the interaction of the hull with the water agitated vessel used in the study oscillations of combined methods of theoretical, experimental and practical, statistical, and probabilistic.

3. Due to the high engineering knowledge required in shipping, we need to update each year to the development of technology onboard ships. Analysis of oscillations of the vessel in waves relies on the fact that it has, in the space, six degrees of freedom, namely: the feed (the longitudinal movement of the axis Gx); derivatives (Gy lateral displacement of the axis), vertical movement (axis Gz); roll (rotation around axis Gx); pitching (rotation around the axis Gy); pivoting (rotation around the axis Gz). However, for practical interest roll, pitch and vertical movement, pure or combined forms. In their study, it supports two reference systems, namely: a fixed system, with the origin in the plane of the free surface of the water still and the same vertical center of gravity G, a mobile system with the origin at the center of gravity and that moves along with it. Typically, in normal operating conditions, if the advance produces, derivatives, and pivoting, the vessel does not return to its original position. If the vertical movement ship roll and pitch oscillations often run free or maintained.

Fluctuations ship undesirable effect of which reads: boarding water on deck in the bow danger of flooding; the emergence of vertical acceleration at critical points (bridge, engine room, and social spaces); loss of speed, directly dependent on the agitation of the sea; out of the water the propeller blades (propellers) and here Fatigue engine (engine) and worsening main operating conditions of equipment and mechanisms onboard; Water hitting the bottom of the vessel (the effect of slamming, wiping and wetness).

Loss of speed while navigating the waves are caused by increasing drag due to ship oscillations and waves; change the operating mode of the propulsion system in terms of producing strong pitch propeller out part or all of the water; the direct influence of the horizontal movement of the upper layers of participating in the movement of water waves.

In practice, the calculation speed losses can use computer programs, charts (Figure 1), and diagrams on the types of ships, depending on the load, the ship's speed, wave height, and direction. 


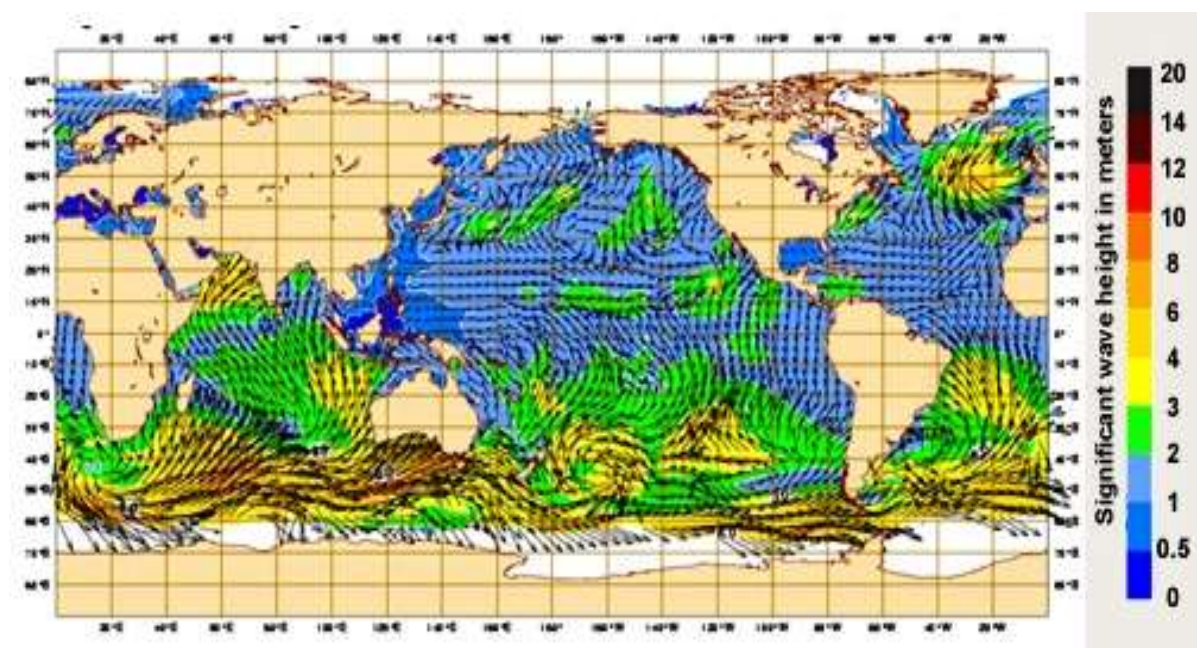

Fig. 1. Analysis of average height and direction of the waves by observation satellites - July 1,2008

Source:https://www.eumetsat.int/jason/print.htm\#page_3.2.0

Navigation in areas with varying currents is a common case of sea transport. In this case of great importance is the knowledge of the influence of the tide, especially in coastal areas, straits, channels, input ports. Education in related subjects to coastal areas, straits, channels, input ports is mandatory.

One problem is that navigation in short currents, wind, whose speed can be determined with a satisfying relationship for the high seas and wind regularly applies for open ocean surfaces for regular winds and constant seawater density.

\section{Conclusion}

Classical and modern methods in maritime education are involved in all transport process related to shipping. Due to the high engineering knowledge required in shipping, we need to update each year to the development of technology onboard ships. Education in related subjects to coastal areas, straits, channels, input ports is mandatory.

\section{References:}

[1] Novac V, Rusu E, Black Sea littoral military operations - environment impact, Scientific Bulletin of Naval Academy, Vol. XXI 2018, pg. 607-616 ;

[2] Novac V, Rusu E and Stăvărache G, Black Sea naval accidents - intervention management, Mechanical Testing and Diagnosis, 2019 (IX), Volume 2, pp. 11-14, ;

[3]V. NOVAC, E. RUSU, I. C. SCURTU, Opportunities and risks related to offshore activities in the western Black Sea, Journal of Environmental Protection and Ecology 20, No 4, 16981707 (2019)

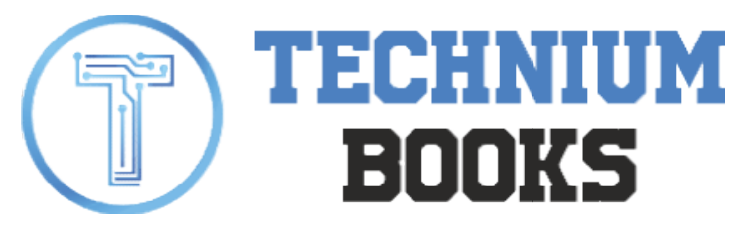




\section{CHAPTER 3}

Gassim H. Dohal, Ph. D.

Tragedy "Teacheth the Uncertainty of this World"

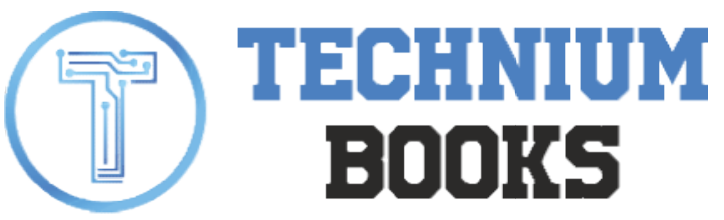




\begin{abstract}
:
In The Defense of Poesy, Sir Philip Sidney argues that tragedy "teacheth the uncertainty of this world." I will explore this statement in three important tragedies: Christopher Marlowe's Doctor Faustus, William Shakespeare's Antony and Cleopatra, and King Lear. In these tragedies, there is the element of risk that is unpredictable, and has no measurable probability. Uncertainty, found in these works, may range from a falling short of certainty to an almost complete lack of definite knowledge especially about an outcome or result of an action or decision taken by a major character in the work in question. In major cases, it appears as if everything were taking place without a prior plan. In the titles I mentioned above, if any of the major characters knows the outcome of his/her decision in advance, s/he will not take such a decision.

In my paper, I will demonstrate how the main characters' risks in their actions have consequences in their lives and affect their future.
\end{abstract}

Key Words: uncertainty, tragedy, Doctor Faustus, Antony and Cleopatra, and King Lear

\title{
Introduction:
}

In The Defense of Poesy (c. 1579-84), Sir Philip Sidney argues that tragedy "teacheth the uncertainty of this world" (118). This is a fair analysis of tragedies like Christopher Marlowe's Doctor Faustus (c. 1588-9), William Shakespeare's Antony and Cleopatra (c. 1606-7), and King Lear (c. 1605-6). In these tragedies, there is the element of risk that is unpredictable, and has no measurable probability. Uncertainty in these works may range from a falling short of certainty to an almost complete lack of definite knowledge especially about an outcome or result of an action or decision taken by a major character in the work in question. In major cases, it appears as if everything were taking place without a prior plan. In the titles I mentioned above, if any of the major characters knows the outcome of his/her decision in advance, s/he will not take such a decision. I will try to explore the three tragedies listed above and how each "teacheth the uncertainty of this world" in the following few pages.

\section{TEXT \& ARGUMENT:}

In Christopher Marlowe's Doctor Faustus, Doctor Faustus thinks that he will have the power he dreams of, but he does not pay attention to the fact that the power he is seeking is a fake, a disguised power that will have limits and will end. In other words, he is thinking of his present, and is not worried about the consequences of his decision. It is not surprising that, at last, he is a Renaissance person who is deceived by his blind belief in the power of his world. Faustus is intoxicated with the rapid expansion of knowledge at his time, and filled with pride in the power of the human mind. This power is countered by the Christian faith where man's knowledge and power are nothing in comparison to God's. Faustus does what the devils have done; he rejects God's supremacy, and challenges God's grace for knowledge and power. But he does not realize that this rejection and challenge will lead him to his destruction. He is self-deceived; he becomes unaware of the reality and certainty of his situation. Otherwise, he will not give his soul for trifles. Who can believe that a great German philosopher sinks to the level of petty tricks, and finally consoles himself by conjuring up Helen of Troy — who is really only a devil in disguise? 
As a matter of fact, at the beginning of the play Faustus arrives at truths - the limitations of his knowledge and power - that he lays out before himself for examinations. As a Renaissance person, these truths call out in him new questions and contradictions. In his speeches and soliloquies, the voice of doubt and irresolution has taken the place of argument for a specific plan or studied sequences. It is the soliloquy of doubt and uncertainty of a Renaissance man we find through the play untill at last the moment of justice comes. At this moment, we have a true soliloquy, the utterance of a tragic hero who gains self-knowledge at the moment when he has no chance to correct his mistakes:

\section{The devil will come, and Faustus must be damn'd.

$$
\text { Or, I'll leap up to my God! —Who pulls me down? }
$$

(XIX. 151-52).

This quotation shows how this man has not been thinking of this moment before.

Anyhow, at the end his pride turns to despair since he has wasted his time in irresolution. His life and death are a warning of a man caught between two worlds: Renaissance pride and Christian faith, a man who adopts, practices, and indeed lives one world, unaware and uncertain of the result of his decision. It is Faustus's tragedy that his aims so consume him as to blind him to his actual case. He deceives and dramatizes himself until he is left at the end with nothing but despair. If he knows or expects from the beginning that this will be his end, he would not carry out such an action.

To make a long story short, Faustus, who began by expressing confidence in his power to manipulate time, ends by his expressing his desire to hold up its course: "That time may cease, and midnight never come" (XIX. 44). As a matter of fact, the complexity of Faustus's moral nature is more like that of any Renaissance man, and out of it he spins the thread of his unplanned, unknown tragic fate. Another tragedy that teaches the uncertainty of this world is William Shakespeare's Antony and Cleopatra. In this play, we find the characters' lack of definite knowledge about any sequences of their decisions and actions. What seems certain and planned in Rome turns out to become uncertain and happens naturally in Egypt. From the very beginning of the tragedy, Rome is seen and depicted as prudent, disciplined, and representing conquest while Egypt represents fertility, pleasure, and love. A reader will expect the play to end as it began, stressing this statement. But what happens is something else where the Egyptian Queen becomes a tragic heroine. According to a Roman view, their admired military leader is enslaved, not to the acknowledged Queen of Egypt, but to a strumpet, a mere gypsy. Yet Shakespeare has contrived to present Cleopatra in all her infinite varietycoquettish, even at times shrewish, but still a noble empress, descended of royal kings on the contrary of the Roman point of view.

Ironically, it is Antony who is seen as torn between his military interests and his emotional ones; at times indecisive and vacillating. He never takes advantage of his supreme military power on land and decides, out of vanity, to fight on sea. There is no certitude of the consequences of what he is doing. As a veteran military leader, he is not expected to get involved in a battle for his opponent dares him to do so. At the battle of Actium, he surrenders his military advantage to follow the fleeing Cleopatra. Things happen uncertainly. There is no specific plan to be followed; trying different ways to live peacefully becomes the ultimate goal of a great leader who is not expected to accept any disdain.

Being defeated in the battle, Antony then sues Caesar for permission to live in Athens as a private man. When his suit is refused, he offers to settle the war "sword against sword" (III. Xiii. 36). It seems that when he falls in love with the queen, he is uncertain that his love will lead him to such an end. Love is lower than honor in the Roman world, but Shakespeare depicts love as a natural force with its natural laws that can defeat any power that stands in front of it. Antony is a hero set free from the limits of heroism by a love, which frees him from a commitment to honor for a commitment to life. The certitude of his liberation is also his humiliation and destruction. Things go unplanned and uncertain. Hence, Antony's destruction becomes the outcome. 
On the other hand, Cleopatra is seen as politically shrewd and decisive. She withdraws her fleet leaving the battle for two Roman colonial powers to consume each other. A colonized country like Egypt is neither expected nor planned for to take such an action. Her withdrawal determines the outcome of the battle because Antony follows her leaving the battleground for his enemy. It appears that events are taking place without anticipation or plan. More than this is the end of both main characters; Antony's death is seen as unheroic, a tragic waste whereas Cleopatra's death is seen as a triumph. The contrary should take place at least from the Roman point of view: who says that a strumpet turns to symbolize the triumph whereas a hero's end turns to be a waste? If there is a plan and certainty, a military leader is to achieve a heroic deed at the end for himself and his nation, while such a queen should be marched in Caesar's triumphant procession in Rome. On the contrary, Out of her discretion, she kills herself instead of being humiliated or enslaved by the Romans. She has already realized that going to Rome would mean more humiliation not only for herself, but for her people as well.

However, the reality of Cleopatra's character is conveyed in the following lines:

\section{Then put my tires and mantles on him, whilst \\ I wore his Sword Philippan}

(II. V. 28-29).

The man who rules half of the world has been reduced to masking in women's clothes. This is not the end of a leader whose decisions and actions are studied and planned. It is the end of one whose actions have passed through some sort of chaos where there is no plan taken to determine the consequences of any act.

Another example of the uncertain consequences of taking decisions is King Lear's decision at the beginning of William Shakespeare's King Lear. Though his decision to divide his kingdom among his daughters seems foolish, yet no one expects that his decree will lead to the result with it the tragedy ends. In addition, he seems that he has no little doubt in his daughters' loyalty. On the contrary, the unexpected becomes true in this tragedy: the wicked prosper, the innocents are banished. Things just happen; there is no clear plan or design that will lead to specific consequences and results. Indeed, King Lear has not looked beneath the surface. He has let the ritual appearances replace the internal reality or he has at least refused to distinguish between the two. The certainty of his end is neither planned nor expected.

At the beginning, King Lear is full of authority and assurance as he makes his regal way through the court. He reveals his intention to divide his kingdom among his daughters out of his excessive confidence in his daughters and in his long reign. His speech and ritual ceremony at the beginning suggest a power that demonstrates the stability and certainty of long, unchallenged reign. However, this is exactly what Lear anticipates because of his excessive confidence in the love of his daughters. The daughter with an ingenuous love who refuses to pretend in front of her father is banished. Lear is not certain of the consequences of his action.

In deciding and performing the act of dividing his kingdom, an act which seems both reasonable and generous for a person in King Lear's position, Lear sets in motion a chain of events which show his vulnerabilities not only as a king and a father but also as a man. Though it is foolish to expect to divest oneself of power and responsibility and yet retain the trappings of authority, it is uncertain that his reward will be filial ingratitude. But he is mistaken in expecting kind treatment of his daughters. While their father expects them to run the country safely and peacefully, their real nature appears on the surface after usurping the power. His two wicked daughters, as if they strove to exceed each other in cruelty to their old father, who had been so good to them, by little and little will have abated him of all his train, and all respect.

From a king to a beggar, from commanding millions to being without one attendant is a hard change. Lear does not expect his elder daughters to reduce him to the condition of a ragged, homeless 
madman. No one expects that the king's risky decision to divide his kingdom will lead to such an end. But as two ruthless powers, his elder daughters manipulate his naivety, ignorance, and misunderstanding of the reality of human nature.

The uncertainty of this world is also presented in the death of Cordelia, which is troublesome; because she is the innocent victim of the evil that surrounds her. Whoever reads the play for the first time will expect this character to be rewarded at the end. But Shakespeare refuses to save her just because the massage to save her is too late. The dramatist here seems to represent the ruthless consequences of the evil and chaos in this world. The play seems to show that Lear's decision to divide his kingdom is a mistake since such a division will lead to chaos. The chaos does not need to be planned or anticipated. There is nothing certain about chaos.

\section{Conclusion:}

In conclusion, the three tragedies Doctor Faustus, Antony and Cleopatra, and King Lear teach the uncertainty of this world as Sir Philip Sidney claims in The Defense of Poesy. There is an element of risk in all actions taken by the main characters. Doctor Faustus's soliloquies show how this doctor lives in doubt and irresolution. He is not the person who is worried about plans and consequences; he is the one who is proud of his humanistic power of knowledge. Like Faustus is Antony, the Roman leader in Antony and Cleopatra. Everything seems to be planned and anticipated untill he falls in love with the Egyptian Queen. After that things happen naturally and without fixed direction. His love appears to free him from any limitations or arrangements. What becomes important for him is just to live his private life. When he is denied so, he commits suicide. On the contrary, Cleopatra proves that she is a heroine. She is not merely a wanton, but she is a shrewd politician. Finally, the decision taken by King Lear of King Lear is not far away from Faustus's. Lear's decision sets in motion a chain of events, which manifest his daughters' tyranny and show his vulnerability as a human being.

\section{References:}

Bennett, A.\&Nicholas R. (2004).Introduction to Literature, Criticism and Theory. 3rd ed. Pearson Longman.

Marlow, C. (1969).Doctor Faustus, Drama of the English Renaissance. Ed. M. L. Wine. New York: Random house, Inc.

Shakespeare, W. (1997).Antony and Cleopatra. The Complete Works of Shakespeare. 4th ed. Ed. David Bevington. Longman.

---.(1997).King Lear. The Complete Works of Shakespeare. 4th ed. Ed. David Bevington. Longman.

Sidney, P. (1965).An Apology for poetry or the Defense of Poesy. London: Thomas Nelson and Sons Ltd.

Spingarn, J. E.(2013).A History of Literary Criticism in the Renaissance. 1920. Reprint. London: Forgotten Books.

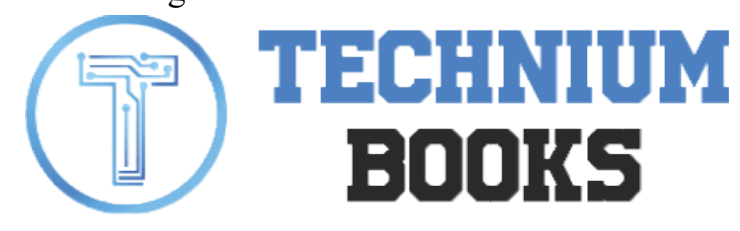




\title{
CHAPTER 4
}

\author{
Andrei-Ionut Perdum
}

Tensile Simulation and CAE Analysis of Fibre Reinforced Polymers (FRP)

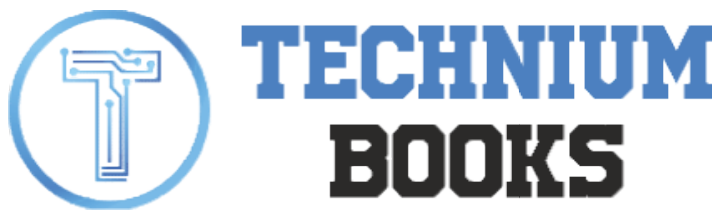


Abstract. This paper describe, how multiple CAE Analysis Simulations were evaluated to verify the influence of the filler in polymer matrix, by checking the differences in weight, density and maximum limit on tensile analysis( $\mathrm{MPa}$ ) for each polymer composite (PAMWCNT \& PA-CF). Fibre reinforced polymer (FRP) composites were incorporated at different loadings of $10 \mathrm{wt} . \%$., 20wt. \%., and $30 \mathrm{wt}$. \%. Statistical Analysis results, reveals that high tensile limit has been achieved, when the addition of $30 \mathrm{wt} . \%$ of CF filler in the PA66 polymer matrix has been added. This paper explore the potential for a novel type of composite material incorporating carbon fibre (CF) and multi walled carbon nanotube (MWCNT). Recent work has shown that notable improvements in mechanical performance are achievable in reinforced polymers [1].

Keywords. MWCNT, Carbon fibre, CAE, Tensile simulation, Fibre reinforced polymer, Mechanical performance.

\section{Introduction}

In nowadays weight reduction has been a challenge for every car manufacturer in the world. Reducing the vehicle weight is now one of the most important things that a car producer should respect when they planning to build a new concept car. The big challenge for the automobile industry is to meet the requirement of global legislation on $\mathrm{CO}_{2}$ outputs per kilometre travelled.

In the European Union for example, from 2021 a fleet average limit will apply of $95 \mathrm{~g} \mathrm{CO}_{2} /$ $\mathrm{km}$ per manufacturer and a penalty of $€ 95$ for every $\mathrm{g}$ of $\mathrm{CO}_{2} / \mathrm{km}$ in excess of this will apply for each registered vehicle. This emission level corresponds to a fuel consumption of around $4.1 \mathrm{l} / 100 \mathrm{~km}$ of petrol or $3.6 \mathrm{l} / 100 \mathrm{~km}$ of diesel [2].

Developing a new material or refreshing the information by adding contribution with new improvements in this side of engineering represents a significantly "brief" for the industry. Having the latest information in your hand will help all the manufactures to take the right decision when they want to develop a new product.

Fibre reinforced polymer (FRP) composites can play a role in vehicle light-weighting due to their excellent specific strength and stiffness. Costs for FRP may be in the range of 20 times that of the equivalent steel structure [3]. This paper explore the potential for a novel type of composite material incorporating carbon fibre (CF) and multi walled carbon nanotube (MWCNT). Recent work has shown that notable improvements in mechanical performance are achievable in reinforced polymers [1].

The aim of this work is to explore the CAE analysis for ISO 527/2, to show the differences in density, mass and tensile simulation, for each type of polymer composite, which were selected carefully for the study.

\section{Materials and Method}

\subsection{Materials}

Polyamide PA66 was used as apolymer matrix in this study. Input data sheet for the products used in simulation wereaccording to the manufacturers. Plasticyl PA1501(from Nanocyl) represent a family of carbon nanotubes, which is especially used for extrusion processes and 
injection molding. Neat Polyamide PA66, density is $1.14 \mathrm{~g} / \mathrm{cm}^{3}$ while the Young Modulus is 2910 (MPa)[4]. Firstconsidered filler was Multi Walled Carbon Nanotube (MWCNT) manufactured by Nanocyl (Belgium), and second filler was represented by Carbon Fibre (CF) supplied by GoodFellow, with a density of $1.28 \mathrm{~g} / \mathrm{cm}^{3}[5]$.

\subsection{Methods}

Fibre reinforced polymer (FRP) composites were considered at different loadings of $10 \mathrm{wt} . \%$. (PA66-10MWCNT \& PA66-10CF), 20wt.\%. (PA66-20MWCNT \& PA66-20CF), and 30wt.\%. (PA66-30MWCNT \& PA66-30CF).

In order to obtain data input for Computer Aided Engineering (CAE) Analysis, each filler loading was calculated in Microsoft Excel by using Density formula for Composite Materials according to Equation (1) and results can be found in (Table 1):

$$
\text { (1) }(w t . \%)_{a} \boldsymbol{x}(\rho)_{a}+(w t . \%)_{b} \boldsymbol{x}(\rho)_{b}+(w t . \%)_{c} \boldsymbol{x}(\rho)_{c}=(\rho)_{T}
$$

Where(wt. \%)represent the weight percentage forthe material used, $\boldsymbol{a}, \boldsymbol{b}, \boldsymbol{c}$ representstype of material (PA66, MWCNT, CF)and(g)is density [6].

Calculated data, was used asinput in all simulation and weight part measurement tests, which conducted the entire simulation process.

Table 1:Calculated density for each filler loading in polymer composite.

\begin{tabular}{|l|c|}
\hline \multicolumn{1}{|c|}{ Materials } & $\begin{array}{l}\text { Calculated density }(\mathbf{g}) \mathbf{g} / \\
\mathbf{c m}^{\mathbf{3}}\end{array}$ \\
\hline PA66 & $1.14 \mathbf{g} / \mathbf{c m}^{3}$ \\
\hline $\begin{array}{l}\text { PA66- } \\
\text { 10MWCNT }\end{array}$ & $1.29 \mathbf{g} / \mathbf{c m}^{3}$ \\
\hline $\begin{array}{l}\text { PA66- } \\
\text { 20MWCNT }\end{array}$ & $1.44 \mathbf{g} / \mathbf{c m}^{3}$ \\
\hline $\begin{array}{l}\text { PA66- } \\
\text { 30MWCNT }\end{array}$ & $1.58 \mathbf{g} / \mathbf{c m}^{3}$ \\
\hline PA66-10CF & $1.19 \mathbf{g} / \mathbf{c m}^{3}$ \\
\hline PA66-20CF & $1.24 \mathbf{g} / \mathbf{c m}^{3}$ \\
\hline PA66-30CF & $1.28 \mathbf{g} / \mathbf{c m}^{3}$ \\
\hline
\end{tabular}

\subsection{Type of test specimen}

For this study has been used ISO 527/2-specimen type 1A, which is used for directly-molded multipurpose test specimens. This represent the test conditions to determine the tensile properties of molding and extrusion plastics [7]. Because is a simulation CAE only, there was not required any post preparation or spare parts for machine calibration.

\section{Simulation program}

Computer Aided Engineering (CAE) is widely accepted method to predict the performance of a studied material under specific circumstances and perform a sensitivity analysis on the 
variables. The properties of the materials are integrated into the $3 \mathrm{D}$ model, to simulate loading in tensile of the sample. Simulation is performed using CATIA -V5, software developed by DassaultSystemes [8].

Mass (g) has been calculated for each test specimen with measure inertia tool from CATIAV5. As can be seen below, in Figure 1, adding 30\% filler in the mixture, has been impacted significantly the weight of the final part, by adding 4 grams on top, taking as reference the initial part.

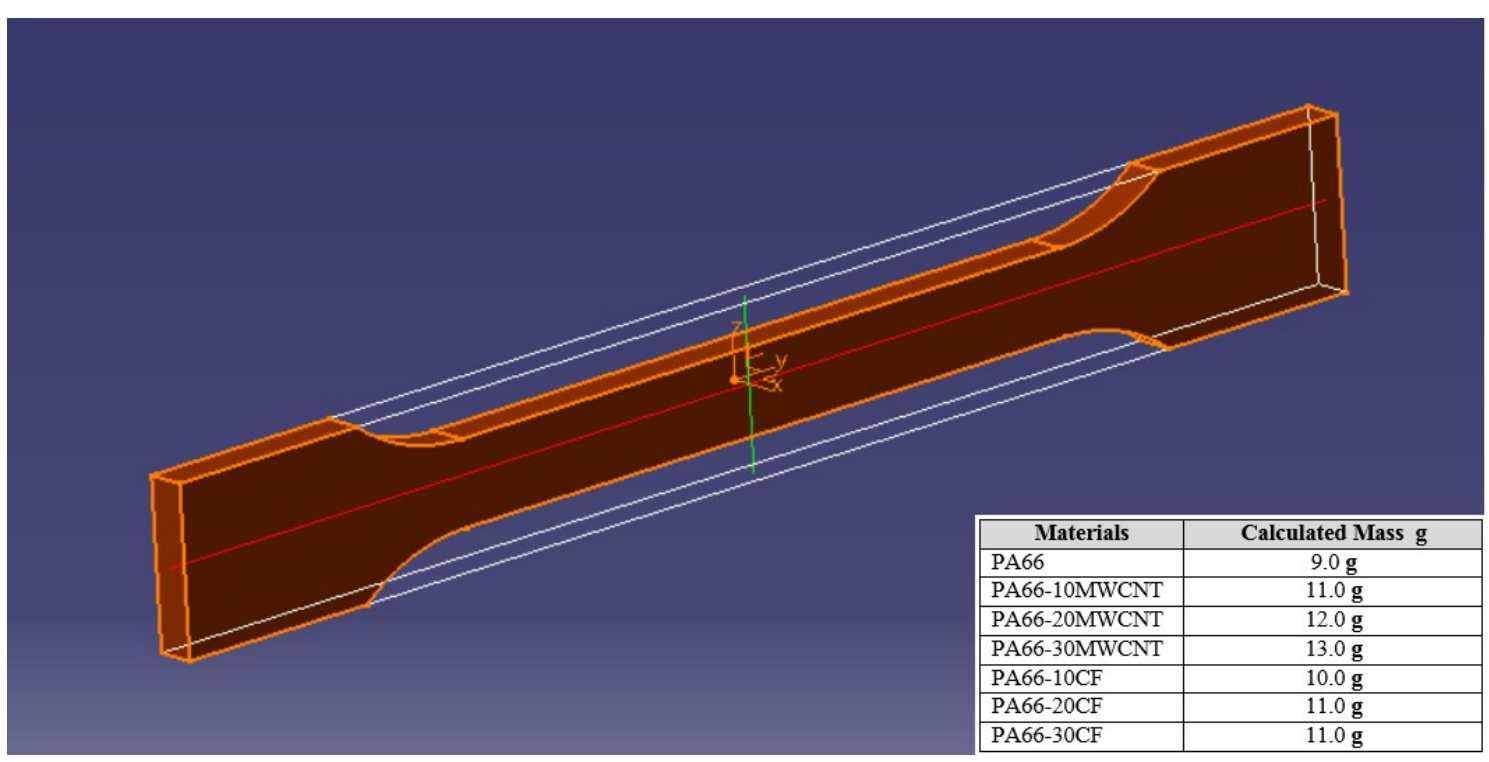

\section{Figure.1: Calculated Mass (g) in Catia-V5, measured withinertia tool, for each} composite material.

Based on ISO 527/2, CAE Tensile Analysis tests were conducted for each compounded material. In real life this test is performed on a table top universal testing machine. A $5 \mathrm{kN}$ or $10 \mathrm{kN}$ system is most usual, but as composites increase in strength, higher charge is required, such as $30 \mathrm{kN}$ or $50 \mathrm{kN}$.For the sake of this study, has been used a Tensile Force of $35 \mathrm{kN}$ [9].

In real life it is mandatory alsoto measure each test specimen before and after tensile test, in order to get accurate data results [7]. Because this study has been entirely conducted with Simulation Software, measurement phase for each specimen was skipped, as these details were carefully checked when 3D model was created. 


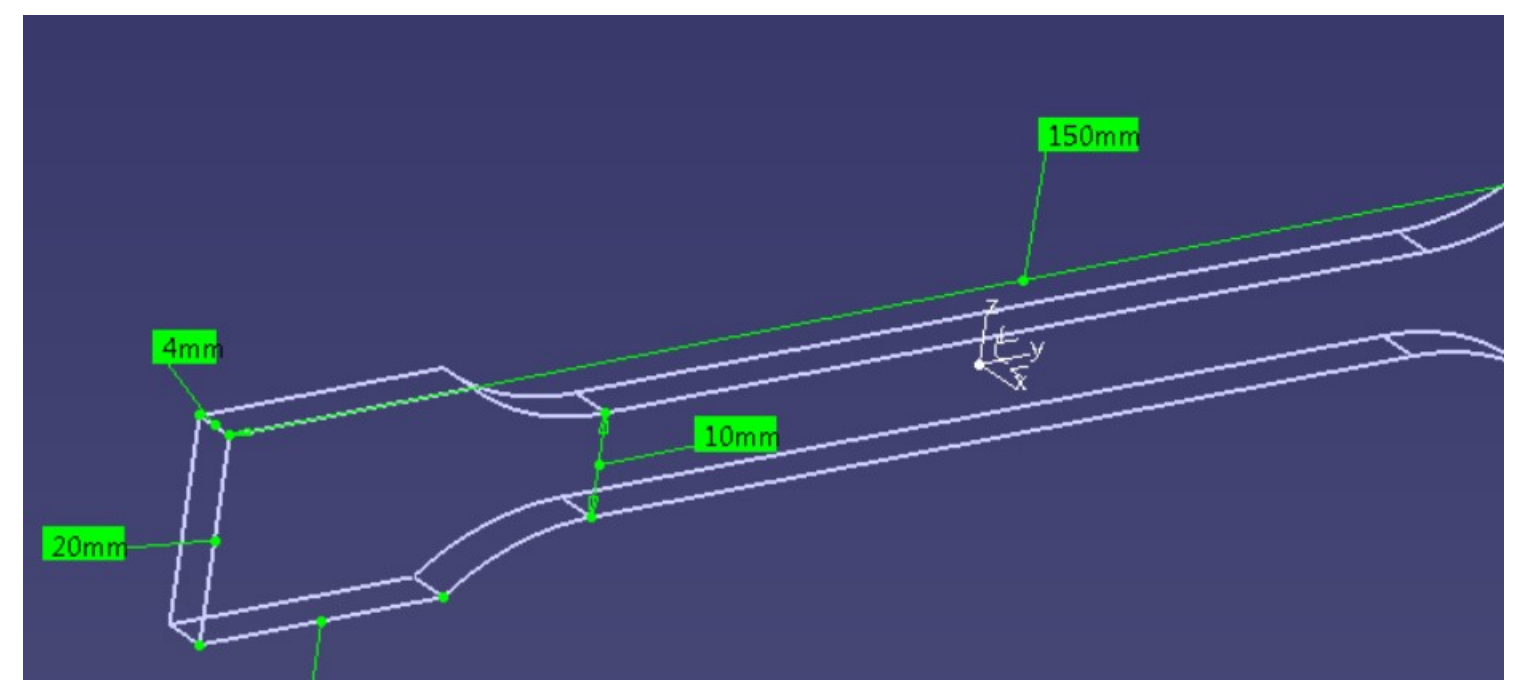

Figure 2: CATIA -V5 measurement for ISO 527/2 - type 1 A.

Tensile Simulation tests were conducted for each type of specimen with CATIA V5, using Analysis \& Simulation $\rightarrow$ General Structural Analysis Tool.

Based on below test results (Table 2, Table 3 and Table 4)can be seen how thestress has beenimpacted, when fibre reinforced polymers was used at different ratio loading. Also the average length specimen distortion has been observed as well before and after test (Figure 3).

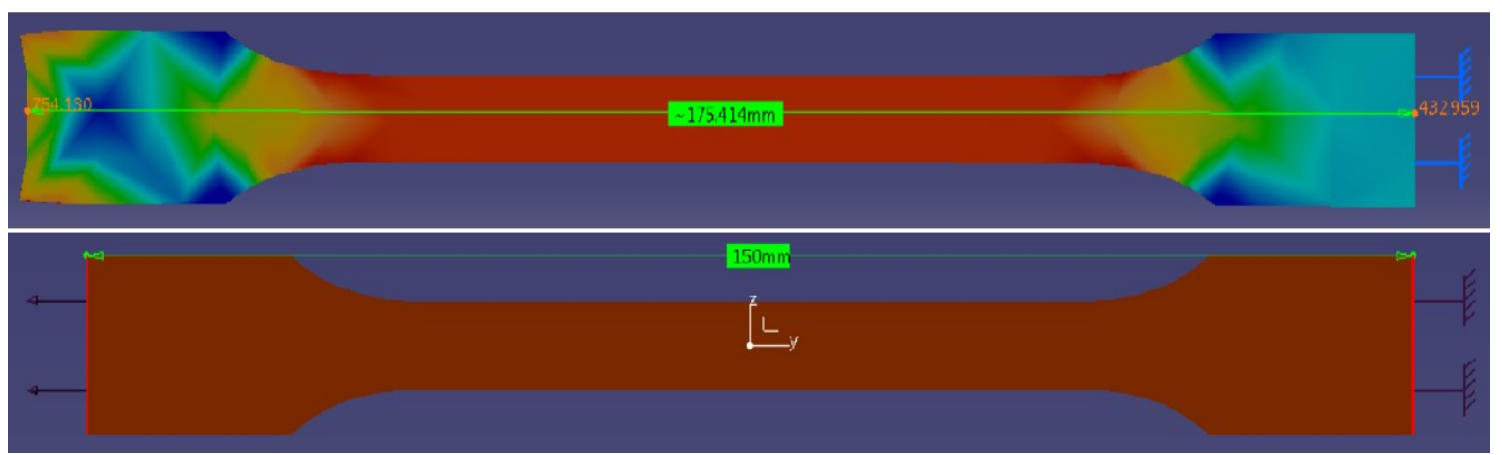

Figure 3: Test specimen view before $(150 \mathrm{~cm}$ length) and after $(175.4 \mathrm{~cm}$ length) tensile simulation. 
Table 2: Test results of Von Mises Stresses - volume distortion energy density and state of stress.

\begin{tabular}{|c|c|}
\hline 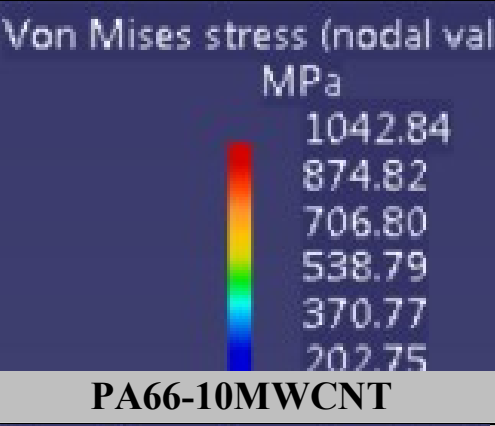 & $\begin{array}{l}\text { Von Mises stress (nodal val } \\
\qquad \begin{array}{c}\text { MPa } \\
1055.49 \\
884.92 \\
714.36 \\
543.80 \\
373.24 \\
202.68\end{array} \\
\text { PA66-10CF }\end{array}$ \\
\hline 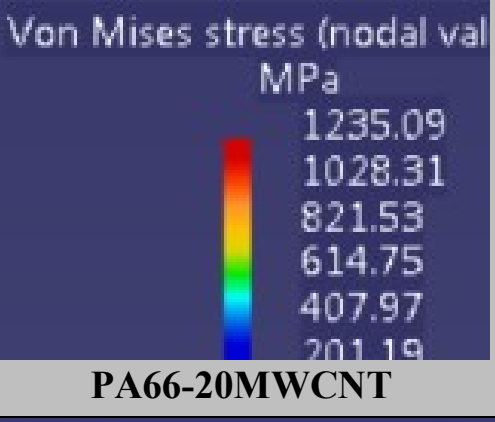 & $\begin{array}{l}\text { Von Mises stress (nodal val; } \\
\qquad \begin{array}{c}\text { MPa } \\
1249.86 \\
1038.07 \\
826.29 \\
614.50 \\
402.71 \\
100.9\end{array} \\
\text { PA66-20CF }\end{array}$ \\
\hline 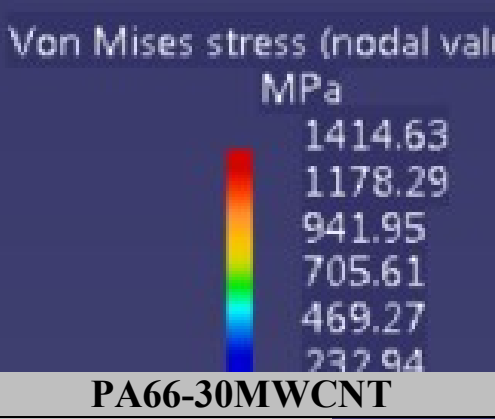 & 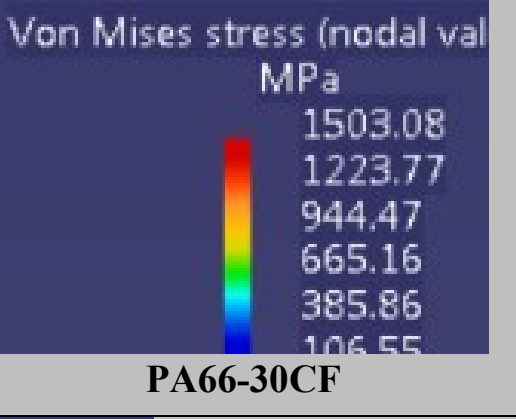 \\
\hline \multicolumn{2}{|c|}{$\begin{array}{l}\text { Von Mises stress (́nodal val } \\
\qquad \begin{array}{l}\text { MPa } \\
1031.69 \\
865.53 \\
699.38 \\
533.22 \\
367.07\end{array}\end{array}$} \\
\hline
\end{tabular}


Table 3: Test specimen view offibre reinforced polymers at different ratio loading, after tensile analysis.

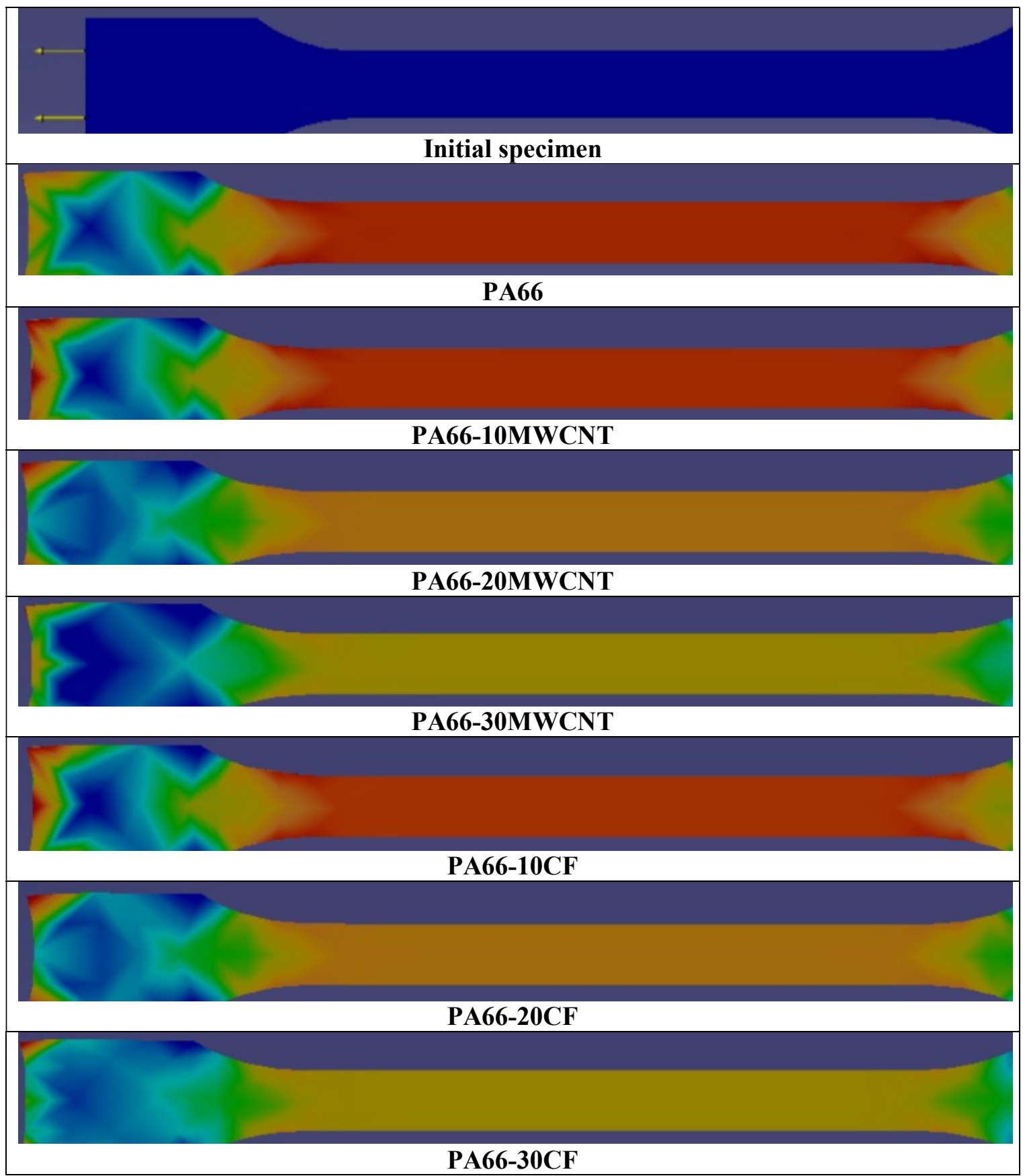

Table 4: Test results of Von Mises Stresses - volume distortion energy density and state of stress, based on minimum and maximum stress limit. 


\begin{tabular}{|l|c|c|}
\hline \multirow{2}{*}{ Materials } & \multicolumn{2}{c|}{ Von Mises Stresses (MPa) } \\
\cline { 2 - 3 } & Minimum Stress limit & Maximum Stress limit \\
\hline PA66 & 200.91 & 1031.69 \\
\hline PA66-10MWCNT & 202.75 & 1042.84 \\
\hline PA66-20MWCNT & 201.19 & 1235.09 \\
\hline PA66-30MWCNT & 232.94 & 1414.63 \\
\hline PA66-10CF & 202.68 & 1055.49 \\
\hline PA66-20CF & 190.93 & 1249.86 \\
\hline PA66-30CF & 106.55 & 1503.08 \\
\hline
\end{tabular}

\section{Conclusion}

In this study, fibre reinforced polymers composites have been considered with the aim of showing the differences in density, mass and tensile simulation limit, for each type of polymer composite. Density increase has been notable observed when filler was added in the polymer matrix. Within CAE Tensile Analysis, it was observed, that adding $30.0 \mathrm{wt}$. \% CF (carbon fibre) filler in the polymer matrix, the Maximum Stress limit has been increased significantly and improved material properties. This study is represented entirely by CAE simulation and no psychical parts were used; all input data were calculated based on equations in order to have a reference for the further study. All calculations and software simulations might not represent $100 \%$ accurate reference data. A physical study will be conducted in the future, in order to confirm and complete the entire case of this paper.

\section{References}

[1]Influence of interfacial interactions on the mechanical behaviour of hybrid composites of polypropylene / short glass fibres / hollow glass beads. Polymer Testing. https://doi.org/10.1016/j.polymertesting.2020.106418

[2]European Commission - Energy, Climate change, Environment - Climate Action - EU Action - Transport emissions - Road transport: Reducing $\mathrm{CO}_{2}$ emissions from vehicles. https://ec.europa.eu/clima/policies/transport/vehicles/cars. Accessed: 14/02/2021.

[3]A performance versus cost analysis of prepreg carbon fibre epoxy energy absorption structure. Composite Structures. Volume 124, June 2015, Pages 206-213 https://doi.org/10.1016/j.compstruct.2015.01.022

[4]Plasticyl - PA1501 - Polyamide 66 - carbon nanotubes masterbatches, Technical Data Sheet. Document data released: $8^{\text {th }}$ November 2016, www.nanocyl.com.

[5] Polyamide - Nylon 6,6-Carbon Fibre Reinforced, Technical Information, Goodfellow, Document data released: $29^{\text {th }}$ November 2020. www.goodfellow.com. 
[6] How to Determine the Density of Solid Materials, Sciencing, 26th Street, Santa Monica, CA 90404, https://sciencing.com.

[7] ISO 527-2, International Standard, Plastics - Determination of tensile properties, Part 2: Test conditions for moulding and extrusion plastics, Copyright by the International Organization for Standardization, Reference number: ISO527-2:1993(E), 04 July 2005.

[8] CATIA - V5, DassaultSystemes, 10 rue Marcel Dassault, CS 40501, VillacoublayCedex France.

[9] ISO 527-2: Tensile Testing for Plastics, The Definitive Guide to Performing ISO 527-2 Tensile Testing on Plastics, written by Erica Lawrence, Instron United States, www.instron.us

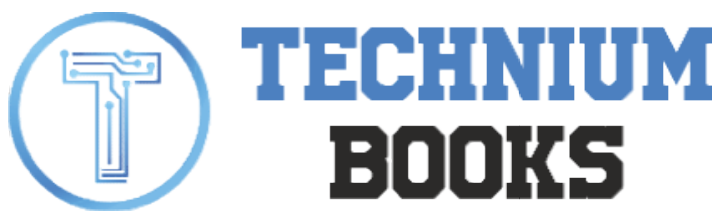

